\title{
Ruthenium(II) complexes of Schiff base derived from cycloalkylamines as pre-catalysts for ROMP of norbornene and ATRP of methyl methacrylate
}

\author{
Maria Beatriz A. Afonso ${ }^{a}$, Thais R. Cruz ${ }^{a}$, Yan F. Silva ${ }^{a}$, João Clécio A. Pereira ${ }^{b}$, \\ Antonio E.H. Machado ${ }^{\mathrm{c}}$, Beatriz E. Goi ${ }^{\mathrm{a}}$, Benedito S. Lima-Neto ${ }^{\mathrm{b}}$, \\ Valdemiro P. Carvalho-Jr ${ }^{\text {a, * }}$ \\ ${ }^{a}$ Faculdade de Ciências e Tecnologia, UNESP Univ Estadual Paulista, CEP 19060-900, Presidente Prudente, SP, Brazil \\ ${ }^{\mathrm{b}}$ Instituto de Química de São Carlos, Universidade de São Paulo, CEP 13560-970, São Carlos, SP, Brazil \\ c Instituto de Química, UFU Universidade Federal de Uberlândia, CEP 38400-902, Uberlândia, MG, Brazil
}

\section{A R T I C L E I N F O}

\section{Article history:}

Received 4 August 2017

Received in revised form 18 September 2017

Accepted 28 September 2017

Available online 30 September 2017

\section{Keywords:}

Schiff base

Ruthenium complexes

ROMP

ATRP

Norbornene

Methyl methacrylate

\begin{abstract}
A B S T R A C T
Ruthenium(II) complexes of Schiff base derived from cycloalkylamines (cycloalkyl = cyclopentyl (1a), cyclohexyl (1b), cycloheptyl (1c), and cyclooctyl) (1d) were synthesized: [RuCl(CyPen-Salen) $\left(\mathrm{PPh}_{3}\right)_{2}$ ] (2a), [RuCl(CyHex-Salen) $\left.\left(\mathrm{PPh}_{3}\right)_{2}\right]$ (2b), [RuCl(CyHep-Salen)( $\left.\left(\mathrm{PPh}_{3}\right)_{2}\right](\mathbf{2 c})$, and [RuCl(CyOct-Salen)( $\left.\left.\mathrm{PPh}_{3}\right)_{2}\right]$ (2d). The Schiff base-Ru ${ }^{\text {II }}$ complexes $2 a-d$ were characterized by elemental analysis, FTIR, UV-Vis, ${ }^{1} \mathrm{H}-,{ }^{13} \mathrm{C}$ and ${ }^{31} \mathrm{P}$ NMR, and cyclic voltammetry. The complexes $2 a-\mathbf{d}$ were evaluated as catalytic precursors for ROMP of norbornene (NBE) and for ATRP of methyl methacrylate (MMA). The syntheses of polynorbornene (polyNBE) via ROMP with complexes 2a-d as pre-catalysts were evaluated under different reaction conditions $([\mathrm{HCl}] /[\mathrm{Ru}],[\mathrm{EDA}] /[\mathrm{Ru}],[\mathrm{NBE}] /[\mathrm{Ru}]$, and temperature). The highest yields of polyNBE were obtained with $[\mathrm{NBE}] /[\mathrm{HCl}] /[\mathrm{Ru}]=5000 / 25 / 1 \mathrm{M}$ ratio in the presence of $5 \mu \mathrm{L}$ of EDA for $60 \mathrm{~min}$ at $50{ }^{\circ} \mathrm{C}$. MMA polymerization via ATRP was conducted using the complexes 2a-d in the presence of ethyl$\alpha$-bromoisobutyrate (EBiB) as initiator. The catalytic tests were evaluated as a function of the reaction time using the initial molar ratio of $[\mathrm{MMA}] /[\mathrm{EB} i \mathrm{~B}] /[\mathrm{Ru}]=1000 / 2 / 1$ at $85{ }^{\circ} \mathrm{C}$. The linear correlation of $\ln \left([\mathrm{MMA}]_{0} /[\mathrm{MMA}]\right)$ and time indicates that the concentration of radicals remains constant during the polymerization and that the ATRP of MMA mediated by $\mathbf{2 a - d}$ proceeds in a controlled manner. Molecular weights increased linearly with conversion, however, the experimental molecular weights were higher than the theoretical ones.
\end{abstract}

() 2017 Elsevier B.V. All rights reserved.

\section{Introduction}

Schiff bases have been playing an important part in the development of coordination chemistry. Schiff base metal complexes have been studied extensively because of their attractive chemical and physical properties and their wide range of applications in numerous scientific areas [1-4]. Concurrently, complexes bearing Schiff base ligands are recognized as homogeneous or heterogeneous catalysts in various organic reactions. Schiff base complexes play a central role in various homogeneous catalytic reactions and the activity of these complexes varies with the type of ligands, coordination sites and metal ions. Furthermore, such complexes

\footnotetext{
* Corresponding author.

E-mail address: valdemiro@fct.unesp.br (V.P. Carvalho-Jr).
}

have recently attracted much attention for oxidation, epoxidation, hydrogenation, miscellaneous, and polymerization reactions $[5,6]$.

In particular, notable works were conducted in ethylene polymerization reactions catalyzed by various metal complexes containing Schiff bases ligands. Aluminum complexes of a series of tridentate Schiff base ligands were found to catalyze the polymerization of ethylene [7]. A number of pyridyl bis(imide) complexes and phenoxy imine complexes are used as catalysts in the polymerization of ethylene [8,9]. Pyridine bis(imine) complexes of iron(III) and cobalt(II) show significant activity in the polymerization of ethylene and copolymerization of ethylene with 1-hexene [10]. The salicylaldiminato complexes of zirconium were found to be effective catalysts in ethylene polymerization and promoted radical decomposition in certain cases [11]. Poly(methylmethacrylate) was prepared in presence of $\mathrm{Cr}$ (III) and $\mathrm{Ni}(\mathrm{II})$ 
salen complexes as catalysts for the controlled radical polymerization of methyl methacrylate (MMA) monomer [12]. Verpoort et al. reported a detailed discussion on catalytic activity in the atom transfer radical polymerization (ATRP) and ring opening metathesis polymerization (ROMP) of various substrates using Schiff bases Ru catalysts [13]. The critical points of these works showed that the efficiencies of catalysts were directly affected by the steric and electronic properties of the ligands. Therefore, the efforts in the easy synthesis of new catalysts and investigation of their activity in ROMP and ATRP reactions are an ongoing interest for the catalysis community.

Herein, we report the facile preparation and evaluation of novel ruthenium(II) complexes of bidentade Schiff bases derived from cycloalkylamines, where the cycloalkyl is cyclopentyl (2a), cyclohexyl (2b), cycloheptyl (2c), and cyclooctyl (2d) (Fig. 1), as precatalysts for ROMP of norbornene (NBE) and ATRP of methyl methacrylate (MMA) under different conditions of temperature, reaction time, and monomer concentration. Ethyl diazoacetate (EDA) was used as carbene source for ROMP and ethyl 2bromoisobutyrate (EBiB) was used as initiator for ATRP. The goal was to observe the ring size influence and its effects on catalytic activity of the studies complexes, discussing the $\sigma$-donor ability and steric hindrance, obtaining resources to understand the factors that influence the efficiency of both reactions. Moreover, base Schiff ligands bound to ruthenium impart good stability and tolerance towards various organic functionalities, air and moisture, widening thus the area of their applications.

\section{Experimental}

\subsection{General remarks}

All reactions and manipulations were performed under nitrogen atmosphere following standard Schlenk techniques. 1,2dichloroethane (DCE) was dried with $\mathrm{CaCl}_{2}$ overnight, filtered, distilled and degassed by three vacuum-nitrogen cycles under nitrogen before use. Methyl methacrylate (MMA) was washed with $5 \% \mathrm{NaOH}$ solution, dried over anhydrous $\mathrm{MgSO}_{4}$, vacuum distilled from $\mathrm{CaH}_{2}$ and stored under nitrogen at $-18{ }^{\circ} \mathrm{C}$ before use. $\mathrm{RuCl}_{3} \cdot \mathrm{xH}_{2} \mathrm{O}, 2,2,6,6$-tetramethyl-1-piperidinoxyl (TEMPO), tetrabutylammonium hexafluorophosphate $\left(n-\mathrm{Bu}_{4} \mathrm{NPF}_{6}\right)$, norbornene (NBE), ethyl diazoacetate (EDA), cyclopentylamine, cyclohexylamine, cycloheptylamine, cyclooctylamine, salicylaldehyde, and ethyl 2-bromoisobutyrate (EBiB) were used as acquired. The $\left[\mathrm{RuCl}_{2}\left(\mathrm{PPh}_{3}\right)_{3}\right]$ complex was prepared following the literature and its purity was checked by satisfactory elemental analysis and spectroscopic examination $\left({ }^{31} \mathrm{P}\left\{{ }^{1} \mathrm{H}\right\}\right.$ and ${ }^{1} \mathrm{H}$ NMR, FTIR and EPR) [14].

\subsection{Analyses}

Elemental analyses were performed with a Perkin-Elmer CHN 2400 at the Elemental Analysis Laboratory of Institute of Chemistry
- USP. ESR measurements from solid sample were conducted at $77 \mathrm{~K}$ using a Bruker ESR 300C apparatus (X-band) equipped with a TE102 cavity and an HP 52152A frequency counter. The FTIR spectra in CsI pellets were obtained on a Bomem FTIR MB 102. Electronic spectra were recorded on a Varian model Cary 500 NIR spectrophotometer, using $1 \mathrm{~cm}$ path length quartz cells. The ${ }^{1} \mathrm{H}$ and ${ }^{31} \mathrm{P}\left\{{ }^{1} \mathrm{H}\right\} N M R$ spectra were obtained in $\mathrm{CDCl}_{3}$ at $298 \mathrm{~K}$ on a Bruker DRX-400 spectrometer operating at 400.13 and $161.98 \mathrm{MHz}$, respectively. The obtained chemical shifts were reported in ppm relative to TMS or $85 \% \mathrm{H}_{3} \mathrm{PO}_{4}$. Conversion was determined from the concentration of residual monomer measured by gas chromatography (GC) using a Shimadzu GC-2010 gas chromatograph equipped with a flame ionization detector and a $30 \mathrm{~m}$ (0.53 mm I.D., $0.5 \mu \mathrm{m}$ film thickness) SPB-1 Supelco fused silica capillary column. Anisole was added to polymerization and used as an internal standard. Analysis conditions: injector and detector temperature, $250{ }^{\circ} \mathrm{C}$; temperature program, $40{ }^{\circ} \mathrm{C}$ (4 min), $20{ }^{\circ} \mathrm{C} \mathrm{min}^{-1}$ until $200{ }^{\circ} \mathrm{C}, 200{ }^{\circ} \mathrm{C}(2 \mathrm{~min})$. The molecular weights and the molecular weight distribution of the polymers were determined by gel permeation chromatography using a Shimadzu Prominence LC system equipped with a LC-20AD pump, a DGU-20A5 degasser, a CBM-20A communication module, a CTO-20A oven at $40^{\circ} \mathrm{C}$ and a RID-10A detector equipped with two Shimadzu column (GPC-805: $30 \mathrm{~cm}, \emptyset=8.0 \mathrm{~mm}$ ). The retention time was calibrated with standard monodispersed polystyrene using HPLC-grade THF as an eluent at $40{ }^{\circ} \mathrm{C}$ with a flow rate of $1.0 \mathrm{~mL} \mathrm{~min}^{-1}$. Electrochemical measurements were performed using an Autolab PGSTAT204 potentiostat with a stationary platinum disk and a wire as working and auxiliary electrodes, respectively. The reference electrode was $\mathrm{Ag} / \mathrm{AgCl}$. The measurements were performed at $25{ }^{\circ} \mathrm{C} \pm 0.1$ in $\mathrm{CH}_{2} \mathrm{Cl}_{2}$ with $0.1 \mathrm{~mol} \mathrm{~L}^{-1}$ of $n-\mathrm{Bu}_{4} \mathrm{NPF}_{6}$.

\subsection{General procedure for the preparation of Schiff-Base Ligands} (1a-d)

To prepare the Schiff base ligands 1a-d, a solution of salicylaldehyde in methanol was slowly added over a solution of the respective cycloalkylamine in methanol. The mixture was stirred at room temperature for $16 \mathrm{~h}$ and the product was obtained as a yellowish orange oil. Any modifications are described below for each reaction.

Schiff-Base Ligand 1a: Salicylaldehyde (0.48 g, $4.0 \mathrm{mmol})$, cyclopentylamine $(0.34 \mathrm{~g}, 4.0 \mathrm{mmol})$, and methanol $(15 \mathrm{~mL})$ afforded $0.60 \mathrm{~g}(80 \%)$ of the title compound as a yellow oil. Refractive index 1.5626; (a) UV-Vis: $\lambda_{\max (\mathrm{n})}(\mathrm{nm}), \varepsilon_{\max (\mathrm{n})}\left[\mathrm{M}^{-1} \mathrm{~cm}^{-1}\right]: \lambda_{\max (1)}$ (317), $\varepsilon_{\max (1)}$ [9600]; (b) IR (KBr): $v_{\mathrm{x}}\left(\mathrm{cm}^{-1}\right): v \mathrm{C}=\mathrm{N}(1629), v \mathrm{C}-\mathrm{O}$ (1277); (c) ${ }^{1} \mathrm{H}$ NMR: $\left(\mathrm{CDCl}_{3}, 400 \mathrm{MHz}\right): 13.8(\mathrm{~s}, 1 \mathrm{H}, \mathrm{OH}), 8.32(\mathrm{~s}, 1 \mathrm{H}$, $\mathrm{CH}=\mathrm{N}), 7.27-7.31\left(\left(\mathrm{dd},{ }^{3} \mathrm{~J}_{\mathrm{H}, \mathrm{H}}=1.6 \mathrm{~Hz}, \mathrm{dd},{ }^{3} J_{\mathrm{H}, \mathrm{H}}=0.8 \mathrm{~Hz}, 1 \mathrm{H}\right.\right.$, salicylring), 7.22-7.24 (dd, ${ }^{3} \mathrm{~J}_{\mathrm{H}, \mathrm{H}}=1.6 \mathrm{~Hz}, 1 \mathrm{H}$, salicyl-ring), 6.93-6.96 (dt, ${ }^{3} J_{\mathrm{H}, \mathrm{H}}=6 \mathrm{~Hz},{ }^{3} J_{\mathrm{H}, \mathrm{H}}=0.4 \mathrm{~Hz}, 1 \mathrm{H}$, salicyl-ring), 6.85-6.88 (td, ${ }^{3} J_{\mathrm{H}, \mathrm{H}}=0.8 \mathrm{~Hz} 1 \mathrm{H}$, salicyl-ring $), 3.75-3.82\left(\mathrm{~m}, 1 \mathrm{H}, \mathrm{CH}^{\text {Pentyl }}\right)$, $1.90-1.99\left(\mathrm{~m}, 2 \mathrm{H}, \mathrm{CH}_{2}^{\text {Pentyl }}\right), 1.81-1.88\left(\mathrm{~m}, 2 \mathrm{H}, \mathrm{CH}_{2}^{\text {Pentyl }}\right), 1.65-1.77$ $\left(\mathrm{m}, 4 \mathrm{H}, \mathrm{CH}_{2}^{\text {Pentyl }}\right),{ }^{13} \mathrm{C}$ NMR $\left(\mathrm{CDCl}_{3}\right) \delta 162.3,161.3,131.8,130.9,118.4$, 116.9, 70, 34.7, 24.5 .
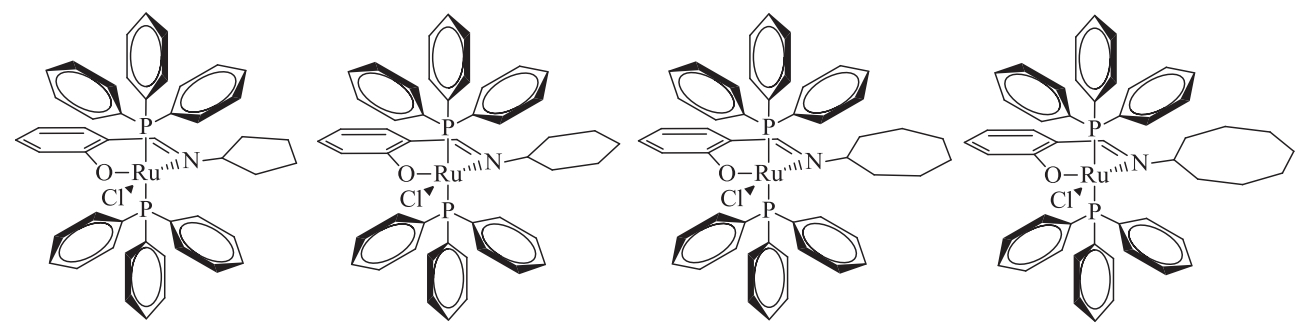

Fig. 1. Illustration of the Schiff base ruthenium(II) complexes (2a-d). 
Schiff-Base Ligand 1b: Salicylaldehyde (0.48 g, $4.0 \mathrm{mmol})$, cyclohexylamine $(0.39 \mathrm{~g}, 4.0 \mathrm{mmol})$, and methanol $(15 \mathrm{~mL})$ afforded $0.68 \mathrm{~g}(85 \%)$ of the title compound as a yellow oil. Refractive index 1.5678; (a) UV-Vis: $\lambda_{\max (\mathrm{n})}(\mathrm{nm}), \varepsilon_{\max (\mathrm{n})}\left[\mathrm{M}^{-1} \mathrm{~cm}^{-1}\right]$ : $\lambda_{\max (1)}$ (317), $\varepsilon_{\max (1)}$ [9700]; (b) IR (KBr): $v_{\mathrm{x}}\left(\mathrm{cm}^{-1}\right): v \mathrm{C}=\mathrm{N}$ (1629), $v \mathrm{C}-\mathrm{O}$ (1274), (c) ${ }^{1} \mathrm{H}$ NMR: $\left(\mathrm{CDCl}_{3}, 400 \mathrm{MHz}\right): 13.83(\mathrm{~s}, 1 \mathrm{H}, \mathrm{OH}), 8.37(\mathrm{~s}, 1 \mathrm{H}, \mathrm{CH}=\mathrm{N})$, $7.31-7.27\left(\mathrm{dd},{ }^{3} \mathrm{~J}_{\mathrm{H}, \mathrm{H}}=1.6 \mathrm{~Hz}, \mathrm{dd},{ }^{3} \mathrm{~J}_{\mathrm{H}, \mathrm{H}}=0.8 \mathrm{~Hz}, 1 \mathrm{H}\right.$, salicyl-ring), 7.23-7.25 (dd, ${ }^{3} J_{\mathrm{H}, \mathrm{H}}=1.6 \mathrm{~Hz}, 1 \mathrm{H}$, salicyl-ring), 6.94-6.98 (dt, ${ }^{3} J_{\mathrm{H}, \mathrm{H}}=6 \mathrm{~Hz},{ }^{3} J_{\mathrm{H}, \mathrm{H}}=0.4 \mathrm{~Hz}, 1 \mathrm{H}$, salicyl-ring), 6.85-6.89 (td, ${ }^{3} J_{\mathrm{H}, \mathrm{H}}=0.8 \mathrm{~Hz}, 1 \mathrm{H}$, salicyl-ring $), 3.22-3.30\left(\mathrm{~m}, 1 \mathrm{H}, \mathrm{CH}^{\mathrm{Hexyl}}\right)$, $1.80-1.87\left(\mathrm{~m}, 4 \mathrm{H}, \mathrm{CH}_{2}^{\text {Hexyl }}\right), 1.50-1.70\left(\mathrm{~m}, 3 \mathrm{H}, \mathrm{CH}_{2}^{\text {Hexyl }}\right), 1.27-1.45$ $\left(\mathrm{m}, 3 \mathrm{H}, \mathrm{CH}_{2}^{\mathrm{Hexyl}}\right) ;{ }^{13} \mathrm{C} \mathrm{NMR}\left(\mathrm{CDCl}_{3}\right) \delta 162.1,161.4,131.9,131.1,118.9$, 118.3, 117.04, 77.3, 77.02, 76.7, 67.4, 25.5, 24.3.

Schiff-Base Ligand 1c: Salicylaldehyde $(0.48 \mathrm{~g}, 4.0 \mathrm{mmol})$, cycloheptylamine $(0.45 \mathrm{~g}, 4.0 \mathrm{mmol})$, and methanol $(15 \mathrm{~mL})$ afforded $0.69 \mathrm{~g}(80 \%)$ of the title compound as a yellow oil. Refractive index 1.5652; (a) UV-Vis: $\lambda_{\max (\mathrm{n})}(\mathrm{nm}), \varepsilon_{\max (\mathrm{n})}\left[\mathrm{M}^{-1} \mathrm{~cm}^{-1}\right]: \lambda_{\max (1)}$ (316), $\varepsilon_{\max (1)}$ [9600]; (b) IR (KBr): $v_{\mathrm{X}}\left(\mathrm{cm}^{-1}\right): \nu \mathrm{C}=\mathrm{N}(1621), v \mathrm{C}-\mathrm{O}$ (1270); (c) ${ }^{1} \mathrm{H}$ NMR: $\left(\mathrm{CDCl}_{3}, 400 \mathrm{MHz}\right): 13.85$ (s, $\left.1 \mathrm{H}, \mathrm{OH}\right), 8.3(\mathrm{~s}, 1 \mathrm{H}$, $\mathrm{CH}=\mathrm{N}), 7.25-7.32\left(\mathrm{dd},{ }^{3} J_{\mathrm{H}, \mathrm{H}}=1.6 \mathrm{~Hz}\right.$, dd, ${ }^{3} J_{\mathrm{H}, \mathrm{H}}=0.8 \mathrm{~Hz}, 1 \mathrm{H}$, salicylring), $7.22-7.25$ (dd, ${ }^{3} J_{\mathrm{H}, \mathrm{H}}=1.2 \mathrm{~Hz}, 1 \mathrm{H}$, salicyl-ring), 6.95-6.98 (dt, ${ }^{3} J_{\mathrm{H}, \mathrm{H}}=6.4 \mathrm{~Hz},{ }^{3} \mathrm{~J}_{\mathrm{H}, \mathrm{H}}=0.4 \mathrm{~Hz}, 1 \mathrm{H}$, salicyl-ring), 6.85-6.89 (td, ${ }^{3} J_{\mathrm{H}, \mathrm{H}}=0.8 \mathrm{~Hz}, 1 \mathrm{H}$, salicyl-ring $), 3.37-3.46\left(\mathrm{~m}, 1 \mathrm{H}, \mathrm{CH}^{\mathrm{Heptyl}}\right)$, $1.82-1.90\left(\mathrm{~m}, 2 \mathrm{H}, \mathrm{CH}_{2}^{\mathrm{Heptyl}}\right), 1.72-1.82\left(\mathrm{~m}, 4 \mathrm{H}, \mathrm{CH}_{2}^{\text {Heptyl }}\right), 1.50-1.70$ $\left(\mathrm{m}, 6 \mathrm{H}, \mathrm{CH}_{2}^{\mathrm{Heptyl}}\right) ;{ }^{13} \mathrm{C} \mathrm{NMR}\left(\mathrm{CDCl}_{3}\right) \delta 161.66,161.39,131.92,131.02$, 118.91, 118.29, 116.99, 77.34, 77.08, 76.83, 70.12, 36.40, 28.54, 24.24.

Schiff-Base Ligand 1d: Salicylaldehyde (0.48 g, $4.0 \mathrm{mmol})$, cyclooctylamine ( $0.51 \mathrm{~g}, 4.0 \mathrm{mmol})$, and methanol $(15 \mathrm{~mL})$ afforded $0.82 \mathrm{~g} \mathrm{(90 \% )}$ of the title compound as a yellow oil. Refractive index 1.5631; (a) UV-Vis: $\lambda_{\max (\mathrm{n})}(\mathrm{nm}), \varepsilon_{\max (\mathrm{n})}\left[\mathrm{M}^{-1} \mathrm{~cm}^{-1}\right]$ : $\lambda_{\max (1)}$ (318), $\varepsilon_{\max (1)}$ [10000]; (b) IR (KBr): $v_{\mathrm{X}}\left(\mathrm{cm}^{-1}\right): v \mathrm{C}=\mathrm{N}(1624), v \mathrm{C}-\mathrm{O}(1278)$; (c) ${ }^{1} \mathrm{H}$ NMR: $\left(\mathrm{CDCl}_{3}, 400 \mathrm{MHz}\right): 13.85(\mathrm{~s}, 1 \mathrm{H}, \mathrm{OH}), 8.3(\mathrm{~s}, 1 \mathrm{H}, \mathrm{CH}=\mathrm{N})$, 7.27-7.32 (dd, ${ }^{3} J_{\mathrm{H}, \mathrm{H}}=1.2 \mathrm{~Hz}$, dd, ${ }^{3} J_{\mathrm{H}, \mathrm{H}}=0.8 \mathrm{~Hz}, 1 \mathrm{H}$, salicyl-ring), $7.22-7.25\left(\mathrm{dd},{ }^{3} J_{\mathrm{H}, \mathrm{H}}=1.2 \mathrm{~Hz}, 1 \mathrm{H}\right.$, salicyl-ring), 6.93-6.97 (dt, ${ }^{3} J_{\mathrm{H}, \mathrm{H}}=6.4 \mathrm{~Hz}, 1 \mathrm{H}$, salicyl-ring), 6.84-6.88 (td, ${ }^{3} J_{\mathrm{H}, \mathrm{H}}=0.8 \mathrm{~Hz}, 1 \mathrm{H}$, salicyl-ring), 3.40-3.45 (m, $\left.1 \mathrm{H}, \mathrm{CH}^{\mathrm{Octyl}}\right), 1.75-1.90\left(\mathrm{~m}, 6 \mathrm{H}, \mathrm{CH}_{2}^{\mathrm{Octyl}}\right)$, $1.45-1.70\left(\mathrm{~m}, 8 \mathrm{H}, \mathrm{CH}_{2}^{\text {Octyl }}\right) ;{ }^{13} \mathrm{C} \mathrm{NMR}\left(\mathrm{CDCl}_{3}\right) \delta 161.7,161.4,131.9,131$, $118.9,118.3,117.04,77.3,77,76.8,70,51.4,35.6,33.47,27.54,25.48$, 23.6.

\subsection{General procedure for the preparation of Schiff-base $R u$ complexes (2a-d)}

Synthesis of the ruthenium(II) Schiff base complexes (2a-d) was accomplished according to the following procedure: To a solution of Schiff base 1a-d in methanol was added dropwise a solution of $\mathrm{NaOH}$ in methanol and the reaction mixture was stirred for $2 \mathrm{~h}$ at room temperature. The deprotonated ligand mixture was transferred by cannula to a 50-mL three-necked flask fitted with a reflux condenser containing the $\left[\mathrm{RuCl}_{2}\left(\mathrm{PPh}_{3}\right)_{3}\right]$ precursor, stirred mixture was refluxed for $4 \mathrm{~h}$. A yellow precipitate was then filtered and washed with methanol and ethyl ether and then dried in a vacuum.

Complex 2a: $\left[\mathrm{RuCl}_{2}\left(\mathrm{PPh}_{3}\right)_{3}\right]$ complex $(0.30 \mathrm{~g}, 0.31 \mathrm{mmol})$, Schiff base $1 \mathrm{a}(0.070 \mathrm{~g}, 0.37 \mathrm{mmol}), \mathrm{NaOH}(0.18 \mathrm{~g}, 0.45 \mathrm{mmol})$, and methanol $(20 \mathrm{~mL})$ afforded $0.25 \mathrm{~g}(80 \%)$ of the title complex as a yellow solid: anal. calculated for $\mathrm{C}_{49} \mathrm{H}_{48} \mathrm{ClNOP}_{2} \mathrm{Ru}$ was $68.01 \mathrm{C}$, $5.59 \mathrm{H}$ and $1.62 \% \mathrm{~N}$; found: $68.34 \mathrm{C}, 5.55 \mathrm{H}$ and $1.60 \% \mathrm{~N}$. UV-Vis: $\lambda_{\max (\mathrm{n})}(\mathrm{nm}), \varepsilon_{\max (\mathrm{n})}\left[\mathrm{M}^{-1} \mathrm{~cm}^{-1}\right]: \lambda_{\max (1)}(252), \varepsilon_{\max (1)}$ [10020], $\lambda_{\max (2)}$ (370), $\varepsilon_{\max (2)}$ [625], $\lambda_{\max (3)}$ (422), $\varepsilon_{\max (3)}$ [240]; IR (KBr): $v_{\mathrm{x}}$ $\left(\mathrm{cm}^{-1}\right): v \mathrm{C}=\mathrm{N}(1618), v \mathrm{C}-\mathrm{O}(1355) ;{ }^{1} \mathrm{H}$ NMR: $\left(\mathrm{CDCl}_{3}, 400 \mathrm{MHz}\right)$ : 7.30-7.70 (m, 12H: metha- $\mathrm{PPh}_{3}$ and $\left.1 \mathrm{H}: \mathrm{CH}=\mathrm{N}\right), 7.30-7.70(\mathrm{~m}, 6 \mathrm{H}$, para- $\left.\mathrm{PPh}_{3}\right), 7.21-7.30\left(\mathrm{~m}, 12 \mathrm{H}\right.$, ortho- $\left.\mathrm{PPh}_{3}\right), 6.63-6.68(\mathrm{~m}, 1 \mathrm{H}$, salicyl-ring), $6.4-6.5\left(\mathrm{dd},{ }^{3} J_{\mathrm{H}, \mathrm{H}}=1.6 \mathrm{~Hz}, \mathrm{dd},{ }^{3} J_{\mathrm{H}, \mathrm{H}}=1.2 \mathrm{~Hz}, 1 \mathrm{H}\right.$, salicyl-ring), 6.04-6.10 (m, 1H, salicyl-ring), 5.85-5.80 (m, $1 \mathrm{H}$, salicyl-ring), $3.85-3.92\left(\mathrm{~m}, 1 \mathrm{H}, \mathrm{CH}^{\text {Pentyl }}\right), 1.60-1.80(\mathrm{~m}, 3 \mathrm{H}$,
$\left.\mathrm{CH}_{2}^{\text {Pentyl }}\right), 1.29-1.38$ ( $\left.\mathrm{m}, 4 \mathrm{H}, \mathrm{CH}_{2}^{\text {Pentyl }}\right), 1.07-1.15\left(\mathrm{~m}, 1 \mathrm{H}, \mathrm{CH}_{2}^{\text {Pentyl }}\right),{ }^{13} \mathrm{C}$ NMR $\left(\mathrm{CDCl}_{3}\right) \delta 166.12,160.83,135.16,135,134.84,134.26,134.21$, 134.16, 132.12, 132.04, 131.93, 131.91, 129, 128.53, 128.44, 127.62, $127.59,127.55,123.36,121.99,111.80,75.92,32.39,23.43 ;{ }^{31} \mathrm{P}\left\{{ }^{1} \mathrm{H}\right\}$ NMR $\left(\mathrm{CDCl}_{3}: \delta, \mathrm{ppm}\right): 43.15$ (s). EPR: no signal was observed.

Complex 2b: $\left[\mathrm{RuCl}_{2}\left(\mathrm{PPh}_{3}\right)_{3}\right]$ complex $(0.30 \mathrm{~g}, 0.31 \mathrm{mmol})$, Schiff base $1 \mathbf{b}(0.075 \mathrm{~g}, 0.37 \mathrm{mmol}), \mathrm{NaOH}(0.18 \mathrm{~g}, 0.45 \mathrm{mmol})$, and methanol $(20 \mathrm{~mL})$ afforded $0.20 \mathrm{~g}(75 \%)$ of the title complex as a yellow solid: anal. calculated for $\mathrm{C}_{50} \mathrm{H}_{50} \mathrm{ClNOP}_{2} \mathrm{Ru}$ was $68.29 \mathrm{C}$, $5.73 \mathrm{H}$ and $1.59 \% \mathrm{~N}$; found: $68.41 \mathrm{C}, 5.64 \mathrm{H}$ and $1.61 \% \mathrm{~N}$. UV-Vis: $\lambda_{\max (\mathrm{n})}(\mathrm{nm}), \varepsilon_{\max (\mathrm{n})}\left[\mathrm{M}^{-1} \mathrm{~cm}^{-1}\right]: \lambda_{\max (1)}(252), \varepsilon_{\max (1)}$ [10050], $\lambda_{\max (2)}$ (369), $\varepsilon_{\max (2)}$ [1766], $\lambda_{\max (3)}$ (420), $\varepsilon_{\max (3)}$ [585]; IR (KBr): $v_{\mathrm{X}}$ $\left(\mathrm{cm}^{-1}\right): v \mathrm{C}=\mathrm{N}(1618), v \mathrm{C}-\mathrm{O}(1342) ;{ }^{1} \mathrm{H}$ NMR: $\left(\mathrm{CDCl}_{3}, 400 \mathrm{MHz}\right):$ 7.30-7.80 (m, 12H: metha- $\mathrm{PPh}_{3}$ and $\left.1 \mathrm{H}: \mathrm{CH}=\mathrm{N}\right), 7.30-7.80(\mathrm{~m}, 6 \mathrm{H}$, para- $\left.\mathrm{PPh}_{3}\right), 7.08-7.30\left(\mathrm{~m}, 12 \mathrm{H}\right.$, ortho- $\left.\mathrm{PPh}_{3}\right), 6.57-6.67(\mathrm{~m}, 1 \mathrm{H}$, salicyl-ring), $6.38-6.51$ (dd, ${ }^{3} \mathrm{~J}_{\mathrm{H}, \mathrm{H}}=1.2 \mathrm{~Hz}$, dd, ${ }^{3} \mathrm{~J}_{\mathrm{H}, \mathrm{H}}=1.6 \mathrm{~Hz}, 1 \mathrm{H}$, salicyl-ring), 5.99-6.12 ( $\mathrm{m}, 1 \mathrm{H}$, salicyl-ring), 5.76-5.89 (dd, $J=0.8 \mathrm{~Hz}, 1 \mathrm{H}$, salicyl-ring), 3.18-3.33 ( $\left.\mathrm{m}, 1 \mathrm{H}, \mathrm{CH}^{\mathrm{Hexyl}}\right), 1.44-1.57$ $\left(\mathrm{m}, 4 \mathrm{H}, \mathrm{CH}_{2}^{\mathrm{Hexyl}}\right), 0.78-1.05\left(\mathrm{~m}, 4 \mathrm{H}, \mathrm{CH}_{2}^{\mathrm{Hexyl}}\right), 0.65-0.78(\mathrm{~m}, 2 \mathrm{H}$, $\left.\mathrm{CH}_{2}^{\mathrm{Hexyl}}\right) ;{ }^{13} \mathrm{C} \mathrm{NMR}\left(\mathrm{CDCl}_{3}\right) \delta 166.03,160.74,135.26,135.10,134.94$, 134.22, 131.98, 128.99, 127.59, 123.40, 122.28, 111.68, 77.24, 76.99, 76.73, 73.17, 33.20, 26.03, 25.84; ${ }^{31} \mathrm{P}\left\{{ }^{1} \mathrm{H}\right\} \operatorname{NMR}\left(\mathrm{CDCl}_{3}\right.$ : $\left.\delta, \mathrm{ppm}\right)$ : 43.37 (s). EPR: no signal was observed.

Complex 2c: $\left[\mathrm{RuCl}_{2}\left(\mathrm{PPh}_{3}\right)_{3}\right]$ complex $(0.30 \mathrm{~g}, 0.31 \mathrm{mmol})$, Schiff base 1c $(0.080 \mathrm{~g}, 0.37 \mathrm{mmol}), \mathrm{NaOH}(0.18 \mathrm{~g}, 0.45 \mathrm{mmol})$, and methanol $(20 \mathrm{~mL})$ afforded $0.23 \mathrm{~g}(85 \%)$ of the title complex as a yellow solid: nal. calculated for $\mathrm{C}_{51} \mathrm{H}_{52} \mathrm{ClNOP}_{2} \mathrm{Ru}$ was $68.56 \mathrm{C}$, $5.87 \mathrm{H}$ and $1.57 \% \mathrm{~N}$; found: $69.19 \mathrm{C}, 5.64 \mathrm{H}$ and $1.64 \% \mathrm{~N}$; UV-Vis: $\lambda_{\max (\mathrm{n})}(\mathrm{nm}), \varepsilon_{\max (\mathrm{n})}\left[\mathrm{M}^{-1} \mathrm{~cm}^{-1}\right]: \lambda_{\max (1)}(246), \varepsilon_{\max (1)}$ [9500], $\lambda_{\max (2)}$ (370), $\varepsilon_{\max (2)}$ [1268], $\lambda_{\max (3)}$ (423), $\varepsilon_{\max (3)}$ [599]; IR (KBr): $v_{\mathrm{X}}\left(\mathrm{cm}^{-1}\right)$ : $v \mathrm{C}=\mathrm{N}(1610), v \mathrm{C}-\mathrm{O}(1337) ;{ }^{1} \mathrm{H}$ NMR: $\left(\mathrm{CDCl}_{3}, 400 \mathrm{MHz}\right): 7.30-7.69$ $\left(\mathrm{m}, 12 \mathrm{H}\right.$ : metha- $\mathrm{PPh}_{3}$ and $\left.1 \mathrm{H}: \mathrm{CH}=\mathrm{N}\right), 7.30-7.69\left(\mathrm{~m}, 6 \mathrm{H}\right.$, para $\left.-\mathrm{PPh}_{3}\right)$, $6.92-7.30\left(\mathrm{~m}, 12 \mathrm{H}\right.$, ortho- $\left.\mathrm{PPh}_{3}\right), 6.60-6.73\left(\mathrm{~d},{ }^{3} J_{\mathrm{H}, \mathrm{H}}=1.6 \mathrm{~Hz}, 1 \mathrm{H}\right.$, salicyl-ring), $6.47-6.56$ (d, ${ }^{3} J_{\mathrm{H}, \mathrm{H}}=1.6 \mathrm{~Hz}, 1 \mathrm{H}$, salicyl-ring), 6.09-6.20 (m, 1H, salicyl-ring), 5.73-5.85 (d, ${ }^{3} J_{\mathrm{H}, \mathrm{H}}=0.8 \mathrm{~Hz}, 1 \mathrm{H}$, salicyl-ring), 3.63-3.77 ( $\left.\mathrm{m}, 1 \mathrm{H}, \mathrm{CH}^{\text {Heptyl }}\right), 1.37-1.64\left(\mathrm{~m}, 4 \mathrm{H}, \mathrm{CH}_{2}^{\text {Hep- }}\right.$ tyl $), 1.27-1.36\left(\mathrm{~m}, 4 \mathrm{H}, \mathrm{CH}_{2}^{\text {Heptyl }}\right), 1.03-1.15\left(\mathrm{~m}, 4 \mathrm{H}, \mathrm{CH}_{2}^{\text {Heptyl }}\right) ;{ }^{13} \mathrm{C}$ $\operatorname{NMR}\left(\mathrm{CDCl}_{3}\right) \delta 166.20,161.6,135.47,135.30,135.14,134.24,134.19$, $134.14,134.03,132.13,132.05,131.96,131.88,128.97,128.68,128.52$, $128.42,127.64,127.60,127.56,123.52,122.78,111.75,75.0,33.32$, 26.6, 25.85, 25.02; ${ }^{31} \mathrm{P}\left\{{ }^{1} \mathrm{H}\right\} \mathrm{NMR}\left(\mathrm{CDCl}_{3}: \delta, \mathrm{ppm}\right): 42.48$ (s). EPR: no signal was observed.

Complex 2d: $\left[\mathrm{RuCl}_{2}\left(\mathrm{PPh}_{3}\right)_{3}\right]$ complex $(0.30 \mathrm{~g}, 0.31 \mathrm{mmol})$, Schiff base 1d $(0.085 \mathrm{~g}, 0.37 \mathrm{mmol}), \mathrm{NaOH}(0.18 \mathrm{~g}, 0.45 \mathrm{mmol})$, and methanol $(20 \mathrm{~mL})$ afforded $0.21 \mathrm{~g}(75 \%)$ of the title complex as a yellow solid: anal. calculated for $\mathrm{C}_{52} \mathrm{H}_{54} \mathrm{ClNOP}_{2} \mathrm{Ru}$ was $68.82 \mathrm{C}$, $6.00 \mathrm{H}$ and $1.54 \% \mathrm{~N}$; found $69.03 \mathrm{C}, 6.21 \mathrm{H}$ and $1.62 \% \mathrm{~N}$. UV-Vis: $\lambda_{\max (\mathrm{n})}(\mathrm{nm}), \varepsilon_{\max (\mathrm{n})}\left[\mathrm{M}^{-1} \mathrm{~cm}^{-1}\right]: \lambda_{\max (1)}(262), \varepsilon_{\max (1)}$ [10000], $\lambda_{\max (2)}$ (377), $\varepsilon_{\max (2)}$ [1528], $\lambda_{\max (3)}$ (426), $\varepsilon_{\max (3)}$ [822]; IR (KBr): $v_{\mathrm{X}}$ $\left(\mathrm{cm}^{-1}\right): v \mathrm{C}=\mathrm{N}(1611), v \mathrm{C}-\mathrm{O}(1336) ;{ }^{1} \mathrm{H}$ NMR: $\left(\mathrm{CDCl}_{3}, 400 \mathrm{MHz}\right)$ : 7.23-7.72 (m, 12H: metha- $\mathrm{PPh}_{3}$ and $\left.1 \mathrm{H}: \mathrm{CH}=\mathrm{N}\right), 7.23-7.72(\mathrm{~m}, 6 \mathrm{H}$, para- $\left.\mathrm{PPh}_{3}\right), 6.95-7.23\left(\mathrm{~m}, 12 \mathrm{H}\right.$, ortho- $\left.\mathrm{PPh}_{3}\right), 6.60-6.67(\mathrm{~m}, 1 \mathrm{H}$, salicyl-ring), $6.52-6.58$ (d, ${ }^{3} J_{\mathrm{H}, \mathrm{H}}=1.6 \mathrm{~Hz}, 1 \mathrm{H}$, salicyl-ring), 6.09-6.16 ( $\mathrm{m}, 1 \mathrm{H}$, salicyl-ring), 5.76-5.80 (m, 1H, salicyl-ring), 3.62-3.76 (m, 1H, CH $\left.{ }^{\text {Octyl }}\right), 1.38-1.50\left(\mathrm{~m}, 4 \mathrm{H}, \mathrm{CH}_{2}^{\text {Octyl }}\right), 1.30-1.36$ $\left(\mathrm{m}, 4 \mathrm{H}, \mathrm{CH}_{2}^{\mathrm{Octyl}}\right), 1.05-1.25\left(\mathrm{~m}, 6 \mathrm{H}, \mathrm{CH}_{2}^{\mathrm{Octyl}}\right) ;{ }^{13} \mathrm{C} \mathrm{NMR}\left(\mathrm{CDCl}_{3}\right)$ $\delta 166.13,161.78,135.12,134.19,134.03,132.12,132.04,131.93,128.99$, 128.53, 128.44, 127.61, 123.50, 122.80, 111.81, 77.25, 77.00, 76.74, $74.85,33.31,26.57,25.84,25.01 ;{ }^{31} \mathrm{P}\left\{{ }^{1} \mathrm{H}\right\} \operatorname{NMR}\left(\mathrm{CDCl}_{3}\right.$ : $\left.\delta, \mathrm{ppm}\right)$ : 42.57 (s). EPR: no signal was observed.

\subsection{ROMP procedure}

In a typical ROMP experiment, $1.1 \mu \mathrm{mol}$ of complex was dissolved in $\mathrm{CHCl}_{3}(2 \mathrm{~mL})$ with an appropriate amount of monomer 
(NBE, $5.5 \mathrm{mmol}$ ) and additive $(\mathrm{HCl}, 27.5 \mu \mathrm{mol}$ ), followed by addition of carbene source (EDA, $43 \mu \mathrm{mol}$ ). Usually the solution gelled for 1-2 min, but the reaction mixture was stirred for $60 \mathrm{~min}$ at 25 or $50{ }^{\circ} \mathrm{C}$ in a silicon oil bath. At room temperature, $5 \mathrm{~mL}$ of methanol was added and the polymer was filtered, washed with methanol and dried in a vacuum oven at $40{ }^{\circ} \mathrm{C}$ up to constant weight. The reported yields are average values from catalytic runs performed at least three times with $10 \%$ error at the most. The isolated polyNBEs were dissolved in THF for GPC data.

\subsection{ATRP procedure}

In a typical ATRP experiment, $12.3 \mu \mathrm{mol}$ of complex was placed in a Schlenk tube containing a magnet bar and capped by a rubber septum. Air was expelled by three vacuum-nitrogen cycles before appropriate amounts of monomer (MMA, $12.3 \mathrm{mmol}$ ), initiator (EBiB, $24.6 \mu \mathrm{mol})$, and DCE $(1 \mathrm{~mL})$ were added. All liquids were handled with dried syringes under nitrogen. The tube was capped under $\mathrm{N}_{2}$ atmosphere using Schlenk techniques, then the reaction mixture was immediately immersed in an oil bath previously heated to the desired temperature. The polymerizations were conducted at $85^{\circ} \mathrm{C}$. The samples were removed from the tube after certain time intervals using degassed syringes. The polymerization was stopped when the reaction mixture became very viscous. The reported conversions are average values from catalytic runs performed at least twice.

\section{Results and discussion}

\subsection{Synthesis and characterization}

The bidentate Schiff bases (1a-d) were readily prepared by condensation of salicylaldehyde with four different cycloalkylamines in methanol (Scheme 1). When $1 \mathrm{~mol}$ of salicylaldehyde and $1 \mathrm{~mol}$ of amine were reacted, the corresponding products were obtained under mild conditions; confirmation of these products was demonstrated by spectroscopic data. As the ligands predominantly exist in the keto tautomeric form in the solid state. Prior to the complexation step an equivalent amount of $\mathrm{NaOH}$ in methanol was added to the ligands to convert this keto form to enolate form. This renders the coordination of enolate oxygen. Equimolar reactions between $\left[\mathrm{RuCl}_{2}\left(\mathrm{PPh}_{3}\right)_{2}\right]$ with the corresponding deprotonated Schiff bases (1a-d) led to the ruthenium(II) Schiff base complexes 2a-d in high yields (Scheme 1).

In the ${ }^{1} \mathrm{H}$ NMR spectra in $\mathrm{CDCl}_{3}$ for the synthesized ligands (1ad) and their complexes (2a-d) are given in Section 2. The peaks in the range $1.0-2.0 \mathrm{ppm}$ for ligands 1a-d and $0.65-2.0 \mathrm{ppm}$ for complexes 2a-d, as multiplets, are assignable to the $\mathrm{CH}_{2}$ groups hydrogens from the $\mathrm{N}$-cycloalkyl substituent. Additionally, the peaks at range 6.84-7.32 ppm for ligands 1a-d and 5.73-6.73 for complexes 2a-d, as multiplets, are assignable to the protons of aromatic $-\mathrm{CH}$ groups. In the ${ }^{1} \mathrm{H}$ NMR spectra of ligands 1a-d and complexes 2a-d, the chemical shifts observed around $8.3 \mathrm{ppm}$ for free ligands and at 7.22-7.50 for complexes 2a-d as singlets are assigned to the proton of azomethine $(-\mathrm{N}=\mathrm{CH}-)$ [15]. The peak due to the azomethine showed a high field shift compared to the free Schiff base after complexation with the metal ion indicating coordination through the azomethine nitrogen atom. A singlet for $\mathrm{OH}$ has a distinct down-field resonance at $13.8 \mathrm{ppm}$, characteristic for the acidic proton involved in a strong intramolecular hydrogen bond in the ligands 1a-d [15]. These signals did not appear in the complexes $\mathbf{2 a - d}$ as expected. The ${ }^{1} \mathrm{H}$ NMR spectra for the complexes 2a-d were dominated by multiplets between 6.92 and $7.80 \mathrm{ppm}$ due to the phenyl protons of two $\mathrm{PPh}_{3}$ ligands coordinated in the $\mathrm{Ru}$ center which are upfield relative to the multiplets around $6.92-7.80 \mathrm{ppm}$ from the aromatic signals for the Schiff base. In the ${ }^{13} \mathrm{C}$ NMR spectra, the carbon peaks between 23.6 and $161.6 \mathrm{ppm}$ for ligands 1a-d and 23.4-166.2 ppm for complexes 2a-d were observed. ${ }^{31} \mathrm{P}$ NMR spectroscopy confirmed the presence of the $\mathrm{PPh}_{3}$ ligands and their magnetic equivalence revealed that the two $\mathrm{PPh}_{3}$ ligands are trans-positioned to each other in the complexes 2a-d since only a singlet around 43 ppm was found for all complexes, thereby minimizing steric repulsion. This orientation is typical for ruthenium Schiff base complexes containing the trans$\left[\mathrm{Ru}\left(\mathrm{PPh}_{3}\right)_{2}\right]$ core [16]. The FTIR spectra of the ligands 1a-d were compared with that of the complexes $\mathbf{2 a - d}$ in order to confirm the coordination of ligand to the ruthenium metal. The infrared spectra of free ligands show the characteristic $\nu(\mathrm{O}-\mathrm{H})$ absorption bands around $2678 \mathrm{~cm}^{-1}$ which disappears after complexation, the absorption corresponding to the $\nu(\mathrm{C}=\mathrm{N})$ vibration is around $1625 \mathrm{~cm}^{-1}$ in the ligands, and it is shifted approximately $12 \mathrm{~cm}^{-1}$ to a lower wavenumber in the spectra of the complexes 2a-d confirming the coordination of azomethine nitrogen to the metal. The coordination of phenolic oxygen of the Schiff bases is supported by

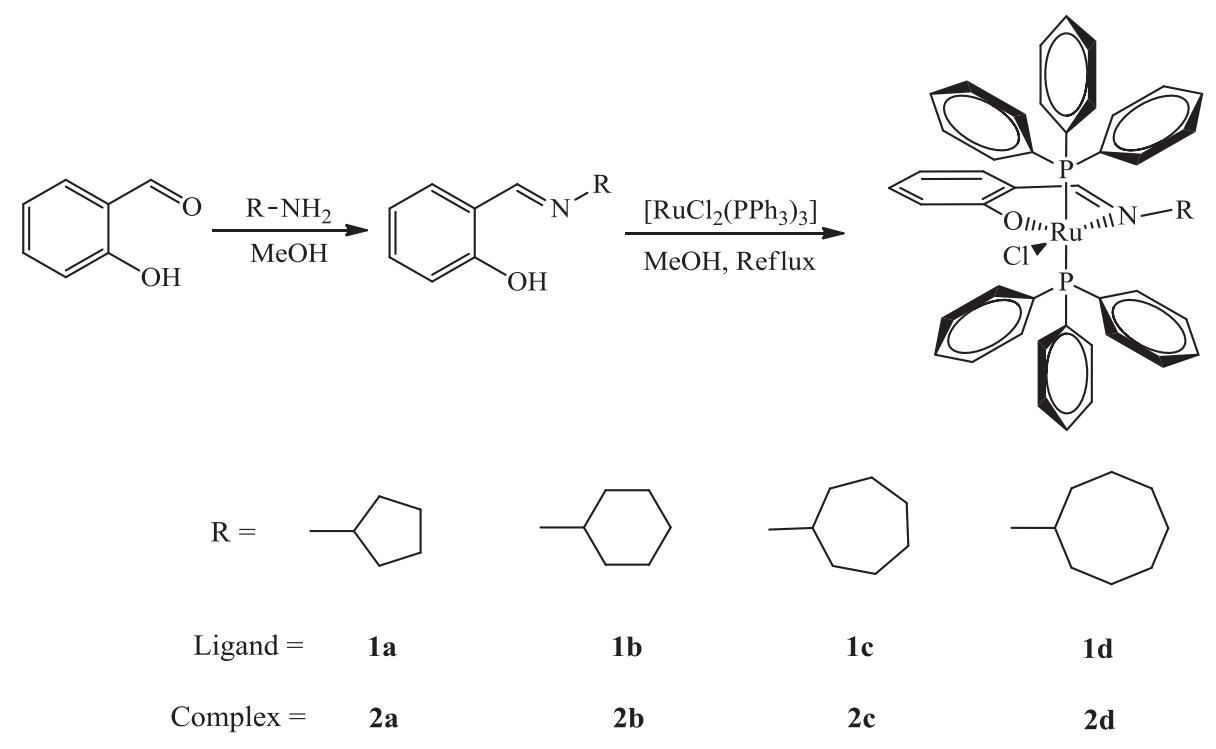

Scheme 1. Synthesis protocol of Schiff base 1a-d and their ruthenium complexes 2a-d. 
the appearance of new bands in $497-499 \mathrm{~cm}^{-1}$ range due to $\nu(\mathrm{Ru}-\mathrm{O})$ stretching in the ruthenium complexes [17]. In addition, these complexes exhibit one strong band in the range $414-417 \mathrm{~cm}^{-1}$, which may be due to $\nu(\mathrm{Ru}-\mathrm{N})$ stretching suggesting coordination of azomethine nitrogen atoms [17].

Electronic spectra of ligands 1a-d and their complexes 2ad have been recorded in the $200-700 \mathrm{~nm}$ range in $\mathrm{CHCl}_{3}$ and their corresponding data are given in Table 1 . The formation of the complexes 2a-d was also confirmed by electronic spectra (Fig. 2). In the electronic spectra of the free ligands and their complexes, the wide range bands were observed due to either the $\pi \rightarrow \pi^{*}$ and $\mathrm{n} \rightarrow \pi^{*}$ of $\mathrm{C}=\mathrm{N}$ chromophore or charge-transfer transition arising from $\pi$ electron interactions between the metal and ligand, which involves either a metal-to-ligand electron transfer [18]. The electronic spectra of the ligands 1a-d in $\mathrm{CHCl}_{3}$ (Fig. 3) showed strong absorption bands in the ultraviolet region (316-318 nm), that could be attributed respectively to the $\pi \rightarrow \pi^{*}$ and $n \rightarrow \pi^{*}$ transitions in the benzene ring or azomethine $(-\mathrm{C}=\mathrm{N})$ groups [19]. In the electronic spectra of the complexes 2a-d, these bands show hypsochromic shifts relative to their free ligands, and they may be hidden under the electronic transition of the $\mathrm{PPh}_{3}$ ligands. This displacement of the absorption bands of the complexes 2a-d most likely originate from the metalation which increases the conjugation and delocalization of the whole electronic system and results in the energy change of the intra-ligand transitions of the conjugated chromophore. These results clearly indicate that the ligand coordinates to metal center, which are in accordance with the results of the other spectroscopic data. Furthermore, the absorption bands in the visible region are observed at between 360 and $426 \mathrm{~nm}$ as a low intensity bands These bands are considered to arise from the MLCT transition [20].

The electrochemical activity of the complexes $\mathbf{2 a - d}$ was studied by cyclic voltammetry in scan rate of $100 \mathrm{mV} \mathrm{s}^{-1}$ in $\mathrm{CH}_{2} \mathrm{Cl}_{2}$ solution containing $0.1 \mathrm{Mn} n-\mathrm{Bu}_{4} \mathrm{NPF}_{6}$ supporting electrolyte in the potential range $0-1.1 \mathrm{~V}$. The cyclic voltammograms of $\mathbf{2 a - d}$ are shown in Fig. 3 and the voltammetric data are summarized in Table 2. On scanning anodically and reversing the scan direction, similar anodic waves which may be attributed to the $\mathrm{Ru}^{\mathrm{II} / \mathrm{III}}$ redox couple and the redox-active phenolate moieties were observed between 0.41 and $0.60 \mathrm{~V}$ and $0.7-1.0$, respectively, for all Schiff base Ru complexes (Fig. 3). Less intense corresponding cathodic peaks were observed; and this may be attributed to the instability and transient nature of the $\mathrm{Ru}^{\mathrm{III}}$ ions in solution. Overall there is a clear

Table 1

Infrared and electronic absorption data for base Schiff ligands 1a-d and their ruthenium complexes $\mathbf{2 a - d}$.

\begin{tabular}{llllll}
\hline \multirow{2}{*}{ Compounds } & FTIR $\left(\mathrm{cm}^{-1}\right)$ & & \multicolumn{2}{l}{ UV-Vis $(\mathrm{nm})$} \\
\cline { 2 - 3 } \cline { 5 - 6 } \cline { 5 - 6 } & Ligand & Complex & & Ligand & Complex \\
\hline 1a/2a & $1277 \nu(\mathrm{C}-\mathrm{O})$ & $416 \nu(\mathrm{Ru}-\mathrm{N})$ & & $317\left(\pi \rightarrow \pi^{*}\right)$ & $252\left(\pi \rightarrow \pi^{*}\right)$ \\
& $1629 \nu(\mathrm{C}=\mathrm{N})$ & $499 \nu(\mathrm{Ru}-\mathrm{O})$ & & $313\left(\mathrm{n} \rightarrow \pi^{*}\right)$ \\
& $2734 \nu(\mathrm{O}-\mathrm{H})$ & $1355 \nu(\mathrm{C}-\mathrm{O})$ & & $370(\mathrm{MLCT})$ \\
& $2952 \nu(\mathrm{C}-\mathrm{H})$ & $1618 \nu(\mathrm{C}=\mathrm{N})$ & & $422(\mathrm{MLCT})$ \\
\hline $\mathbf{1 b} / \mathbf{2 b}$ & $1274 \nu(\mathrm{C}-\mathrm{O})$ & $417 \nu(\mathrm{Ru}-\mathrm{N})$ & $317\left(\pi \rightarrow \pi^{*}\right)$ & $252\left(\pi \rightarrow \pi^{*}\right)$ \\
& $1629 \nu(\mathrm{C}=\mathrm{N})$ & $497 \nu(\mathrm{Ru}-\mathrm{O})$ & & $313\left(\mathrm{n} \rightarrow \pi^{*}\right)$ \\
& $2663 \nu(\mathrm{O}-\mathrm{H})$ & $1342 \nu(\mathrm{C}-\mathrm{O})$ & & $369(\mathrm{MLCT})$ \\
& $2925 \nu(\mathrm{C}-\mathrm{H})$ & $1618 \nu(\mathrm{C}=\mathrm{N})$ & & $420(\mathrm{MLCT})$ \\
\hline 1c/2c & $1270 \nu(\mathrm{C}-\mathrm{O})$ & $416 \nu(\mathrm{Ru}-\mathrm{N})$ & $316\left(\pi \rightarrow \pi^{*}\right)$ & $246\left(\pi \rightarrow \pi^{*}\right)$ \\
& $1621 \nu(\mathrm{C}=\mathrm{N})$ & $497 \nu(\mathrm{Ru}-\mathrm{O})$ & & $273\left(\mathrm{n} \rightarrow \pi^{*}\right)$ \\
& $2662 \nu(\mathrm{O}-\mathrm{H})$ & $1337 \nu(\mathrm{C}-\mathrm{O})$ & & $370(\mathrm{MLCT})$ \\
& $2910 \nu(\mathrm{C}-\mathrm{H})$ & $1610 \nu(\mathrm{C}=\mathrm{N})$ & & $423(\mathrm{MLCT})$ \\
\hline $\mathbf{1 d} / \mathbf{2 d}$ & $1278 \nu(\mathrm{C}-\mathrm{O})$ & $414 \nu(\mathrm{Ru}-\mathrm{N})$ & $318\left(\pi \rightarrow \pi^{*}\right)$ & $262\left(\pi \rightarrow \pi^{*}\right)$ \\
& $1624 \nu(\mathrm{C}=\mathrm{N})$ & $498 \nu(\mathrm{Ru}-\mathrm{O})$ & & $320\left(\mathrm{n} \rightarrow \pi^{*}\right)$ \\
& $2651 \nu(\mathrm{O}-\mathrm{H})$ & $1336 \nu(\mathrm{C}-\mathrm{O})$ & & $377(\mathrm{MLCT})$ \\
& $2904 \nu(\mathrm{C}-\mathrm{H})$ & $1611 \nu(\mathrm{C}=\mathrm{N})$ & & $426(\mathrm{MLCT})$ \\
\hline
\end{tabular}

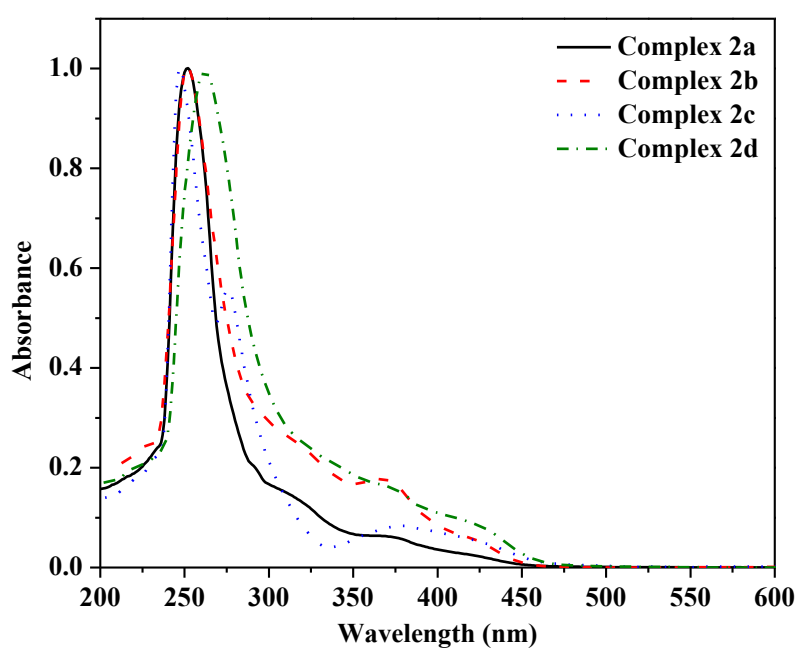

Fig. 2. Electronic spectra of the complexes $\mathbf{2 a - d}$ in degassed $\mathrm{CH}_{2} \mathrm{Cl}_{2}$ solution at room temperature $\left([\mathrm{Ru}]=0.1 \mathrm{mmol} \mathrm{L}^{-1}\right)$.

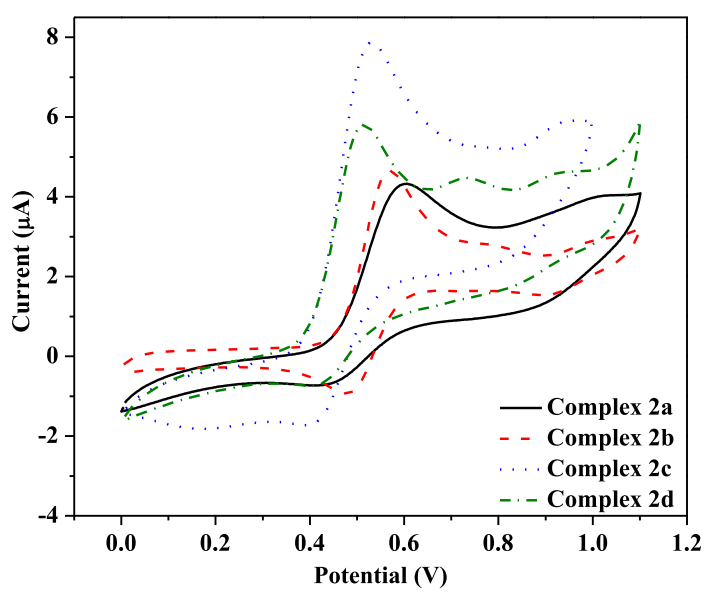

Fig. 3. Cyclics voltammograms of $\mathbf{2 a - d}$ in $\mathrm{CH}_{2} \mathrm{Cl}_{2}$ at $25{ }^{\circ} \mathrm{C}$. $[\mathrm{Ru}]=10 \mathrm{mM}$; $[n$ $\left.\mathrm{Bu}_{4} \mathrm{NPF}_{6}\right]=0.1 \mathrm{M}$. Scanning anodically from 0.0 up to $1.1 \mathrm{~V}$ at scan rates of $100 \mathrm{mV} \mathrm{s}^{-1}$.

Table 2

Cyclic voltammetry ${ }^{\mathrm{a}}$ results for complexes $\mathbf{2 a - d}$

\begin{tabular}{lllll}
\hline Complex & \multicolumn{1}{l}{ CV } & & \\
\cline { 2 - 5 } & $E_{\mathrm{pa}}(\mathrm{V})$ & $E_{\mathrm{pc}}(\mathrm{V})$ & $E_{1 / 2}(\mathrm{~V})$ & $\Delta E_{\mathrm{p}}(\mathrm{V})$ \\
\hline 2a & 0.599 & 0.462 & 0.530 & 0.137 \\
$\mathbf{2 b}$ & 0.568 & 0.483 & 0.525 & 0.085 \\
2c & 0.529 & 0.408 & 0.468 & 0.121 \\
2d & 0.515 & 0.433 & 0.474 & 0.082 \\
\hline
\end{tabular}

a Conditions: $\mathrm{CH}_{2} \mathrm{Cl}_{2}, \quad n-\mathrm{Bu}_{4} \mathrm{NPF}_{6}$ (supporting electrolyte, $0.1 \mathrm{~mol} \mathrm{~L}^{-1}$ ), $[\mathrm{Ru}]=5 \mathrm{mmol} \mathrm{L}^{-1}$, scan rate $=100 \mathrm{mV} \mathrm{s}^{-1}$ ), platinum disk and wire (working and auxiliary electrode), $\mathrm{Ag} / \mathrm{AgCl}$ (reference electrode). $E_{1 / 2}$ is the half-potential for the complex; $\Delta E_{\mathrm{p}}$ is the cathodic-anodic peak separation.

shift in the redox potentials towards more negative values as the electron-donating ability of the cycloalkyl substituents is increased (Octyl > Heptyl > Hexyl > Pentyl). Modulation of the electron-donating ability, as well as the steric effect of the Schiff base ligands is subsequently shown to have an effect on the activity on ROMP and ATRP of the complexes 2a-d.

\subsection{ROMP reactions}

The reactivity of the complexes $\mathbf{2 a - d}$ as catalytic precursors was 
tested on ROMP of NBE in $\mathrm{CHCl}_{3}$ with $[\mathrm{NBE}] /[\mathrm{Ru}]=5000$, volume of $\mathrm{EDA}=5 \mu \mathrm{L}$ at $25^{\circ} \mathrm{C}$ for $60 \mathrm{~min}$ (Fig. 4). In general, the complexes 2ad presented low yields of polyNBE, the complex 2a with lower yield of $4 \%$ and $\mathbf{2 d}$ with higher yield equal to $11 \%$ (Table 3 ). ROMP of NBE with complexes 2a-d was also evaluated at $50{ }^{\circ} \mathrm{C}$ under the same conditions. The increase of temperature produced higher yields of polyNBE, with maximum yields of up to $25 \%$ and PDI values between 1.1 and 2.3. As the temperature increased to $50^{\circ} \mathrm{C}$, the yields practically doubled with a significant increase in $M_{n}$ values of the order from $10^{3}$ to $10^{4} \mathrm{~g} \mathrm{~mol}^{-1}$ in relation to $25^{\circ} \mathrm{C}$. When comparing the reactivity at 25 and $50{ }^{\circ} \mathrm{C}$, the main difference was in the yields of polymer, which the catalytic activity at $50{ }^{\circ} \mathrm{C}$ was always higher than that observed at $25{ }^{\circ} \mathrm{C}$ for all complexes. Thus, the improvement in the catalytic activity of the complexes $2 \mathbf{a}-\mathbf{d}$ at $50{ }^{\circ} \mathrm{C}$ shows that the induction period was favored.

In order to optimize the induction period of the complexes 2ad in the ROMP mechanism, a chemical activation of the catalytic precursors was attempted with the use of $\mathrm{HCl}$ acid. This strategy has already been applied for the activation of ruthenium(II) Schiff bases catalysts, which the acid protonates the $\mathrm{N}$-atom of the azomethine group [13c]. This causes the partial labilization of the Schiff base with generation of a vacancy at the ruthenium center, and the initiation step occurs as monomer is added. The ROMP of NBE catalyzed by the complexes 2a-d in the presence of $\mathrm{HCl}$ is shown in Fig. 4, where the $[\mathrm{HCl}] /[\mathrm{Ru}]$ ratio was investigated to find the optimal concentration of acid.

The catalytic activity of the complexes $\mathbf{2 a - d}$ was sensitive with variation of the $[\mathrm{HCl}] /[\mathrm{Ru}]$ molar ratio at 25 and $50{ }^{\circ} \mathrm{C}$ (Table 3 ). At $25^{\circ} \mathrm{C}$, a considerable increase in the yields of polyNBE as increasing the $[\mathrm{HCl}] /[\mathrm{Ru}]$ ratio up to 25 was observed, followed by a drop for $[\mathrm{HCl}] /[\mathrm{Ru}] \geq 50$. When polymerization was performed at $50{ }^{\circ} \mathrm{C}$ in the presence of acid, a similar profile was observed, although, higher values of polyNBE yields were achieved with $M_{n}$ values near the order of $10^{5} \mathrm{~g} \mathrm{~mol}^{-1}$. It is rationalized that this increase in the catalytic activity of 2a-d can be explained by the protonation of $N$ atom of the Schiff base azomethine group, it creates a vacant site at the ruthenium center to formation of active species. In addition, the
Table 3

Yield values and SEC data from the ROMP of NBE with 2 a-d at 25 and $50{ }^{\circ} \mathrm{C}$; [NBE]/ $[\mathrm{Ru}]=5000$ and $5 \mu \mathrm{L}$ of EDA with $1.1 \mu \mathrm{mol}$ of complex in $\mathrm{CH}_{2} \mathrm{Cl}_{2}$ for $60 \mathrm{~min}$.

\begin{tabular}{|c|c|c|c|c|c|c|c|}
\hline \multirow[t]{2}{*}{ Complex } & \multirow[t]{2}{*}[\mathrm{HCl}]{$/[\mathrm{Ru}]$} & \multicolumn{3}{|l|}{$25^{\circ} \mathrm{C}$} & \multicolumn{3}{|l|}{$50{ }^{\circ} \mathrm{C}$} \\
\hline & & Yield (\%) & $\mathrm{M}_{\mathrm{n}}\left(10^{3}\right)$ & PDI & Yield (\%) & $\mathrm{M}_{\mathrm{n}}\left(10^{3}\right)$ & PDI \\
\hline \multirow[t]{6}{*}{$2 a$} & 0 & 4 & 4.1 & 1.2 & 8 & 98.8 & 2.3 \\
\hline & 10 & 22 & 38.2 & 1.5 & 34 & 94.0 & 3.0 \\
\hline & 25 & 29 & 49.2 & 1.2 & 43 & 87.3 & 1.3 \\
\hline & 50 & 21 & 78.6 & 1.2 & 38 & 62.1 & 1.2 \\
\hline & 150 & 16 & 60.2 & 1.4 & 24 & 97.0 & 3.7 \\
\hline & 300 & 6 & 5.4 & 2.9 & 15 & 15.0 & 2.0 \\
\hline \multirow[t]{6}{*}{ 2b } & 0 & 4 & 8.7 & 1.1 & 10 & 86.0 & 1.1 \\
\hline & 10 & 25 & 46.0 & 3.8 & 37 & 19.3 & 1.5 \\
\hline & 25 & 28 & 68.0 & 3.8 & 43 & 49.2 & 3.2 \\
\hline & 50 & 17 & 79.5 & 1.1 & 17 & 76.4 & 1.1 \\
\hline & 150 & 18 & 56.4 & 3.2 & 18 & 54.4 & 1.2 \\
\hline & 300 & 14 & 9.6 & 1.0 & 13 & 76.5 & 1.1 \\
\hline \multirow[t]{6}{*}{$2 c$} & 0 & 8 & 2.4 & 2.0 & 15 & 68.0 & 1.3 \\
\hline & 10 & 26 & 37.2 & 2.6 & 32 & 60.0 & 3.6 \\
\hline & 25 & 31 & 64.5 & 2.3 & 43 & 32.5 & 1.6 \\
\hline & 50 & 14 & 48.9 & 3.8 & 23 & 70.8 & 1.5 \\
\hline & 150 & 11 & 61.2 & 3.1 & 18 & 71.0 & 1.1 \\
\hline & 300 & 0 & - & - & 11 & 94.6 & 1.1 \\
\hline \multirow[t]{6}{*}{$2 d$} & 0 & 11 & 54.0 & 1.1 & 25 & 96.1 & 1.1 \\
\hline & 10 & 31 & 56.6 & 2.6 & 35 & 48.4 & 3.1 \\
\hline & 25 & 34 & 10.8 & 3.0 & 44 & 72.6 & 1.1 \\
\hline & 50 & 21 & 23.1 & 1.4 & 45 & 83.7 & 1.3 \\
\hline & 150 & 13 & 34.5 & 2.7 & 36 & 90.1 & 2.8 \\
\hline & 300 & 0 & - & - & 2 & 7.7 & 1.1 \\
\hline
\end{tabular}

steric hindrance in the different Schiff bases plays a decisive role in the reactivity in the complexes $2 \mathbf{a}-\mathbf{d}$. Besides that, the order of reactivity of the complexes in ROMP increases from 2 a to $\mathbf{2 d}$. The lability of the azomethine group becomes more favored as the steric hindrance increases, as cycloalkyl substituent is increased from cyclopentyl (2a) to cyclooctyl (2d). However, excess $\mathrm{HCl}$ acid $([\mathrm{HCl}] /[\mathrm{Ru}] \geq 50)$ in the mixture conducted a decreasing in the polyNBE yields. Perhaps, with a very excessive amount of $\mathrm{HCl}$, the chlorides should compete for a coordination site and be able to
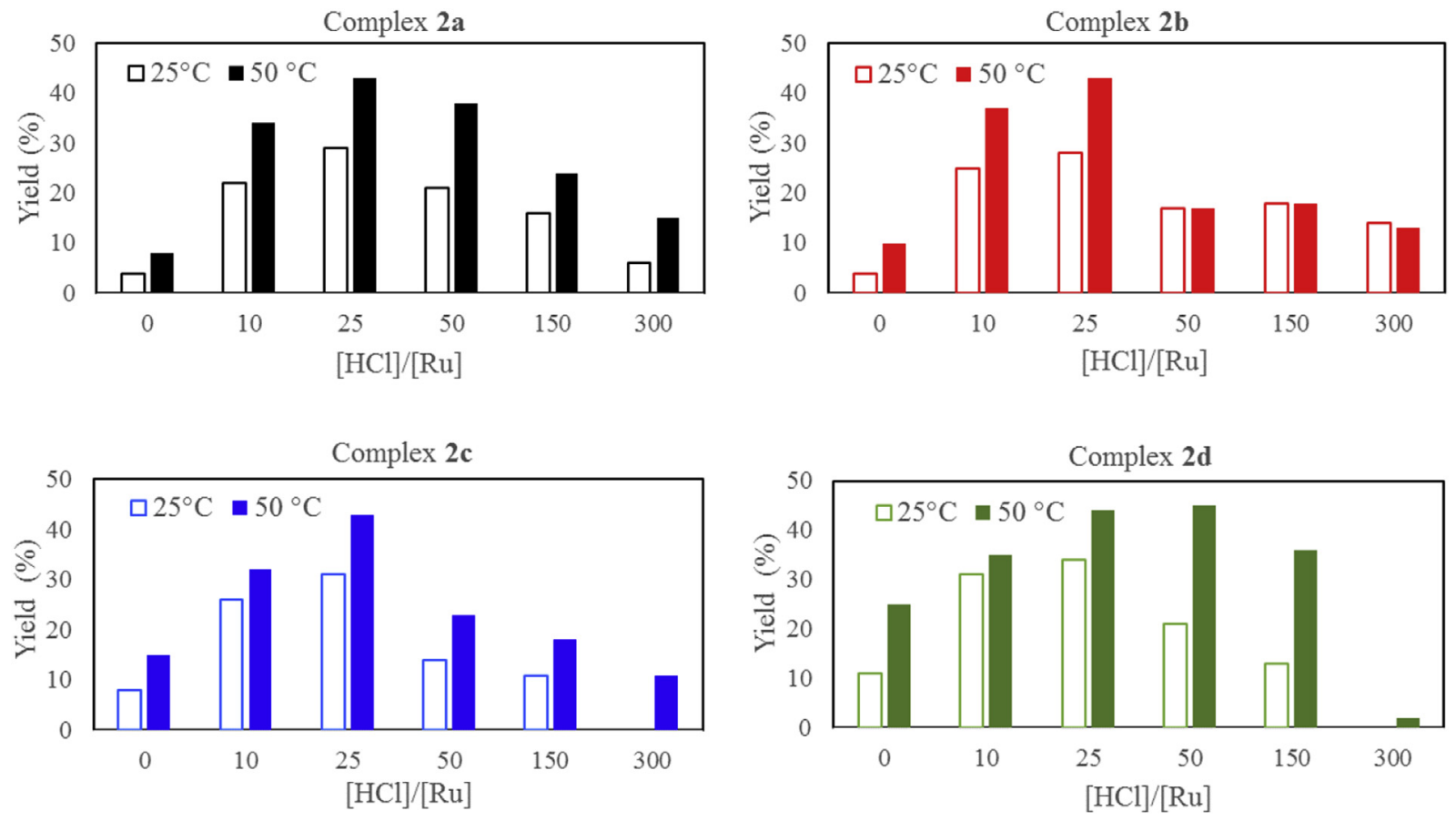

Fig. 4. Dependence of yield on the $[\mathrm{HCl}] /[\mathrm{Ru}]$ molar ratio for ROMP of $\mathrm{NBE}$ with $\mathbf{2 a - d}$; $[\mathrm{NBE}] /[\mathrm{Ru}]=5000$ and $5 \mu \mathrm{L}$ of $\mathrm{EDA}$ in $\mathrm{CH}_{2} \mathrm{Cl}{ }_{2}$ at 25 and $50{ }^{\circ} \mathrm{C}$ for $60 \mathrm{~min}$. 
coordinate to the ruthenium center, causing the degradation of the complex in solution by full release of the Schiff base of the coordinating sphere.

ROMP of NBE with the complexes 2a-d was conducted varying the volume of EDA (Fig. 5), the polymerizations were carried out by keeping the optimal concentration of acid found $([\mathrm{HCl}] /[\mathrm{Ru}]=25)$ at $25^{\circ} \mathrm{C}$. No formation of polymer was observed in the absence of EDA. An increase in polyNBE yields is observed by increasing the volume of EDA up to $5 \mu \mathrm{L}$. For higher volumes of EDA ( $\geq 10 \mu \mathrm{L})$, a decreasing in yields is observed. In general, the $M_{n}$ values also follow this trend with an increase of the molecular weights up to $5 \mu \mathrm{L}$ followed by decreases to higher volumes of EDA $(\geq 10 \mu \mathrm{L})$ with PDI values ranging from 1.1 to 3.0. (Table 4). The increase of polyNBE yields with increasing volume of EDA up to $5 \mu \mathrm{L}$ is indicative of the coordination of EDA with associative character. However, it should be noted that a very excessive amount of EDA $(\geq 10 \mu \mathrm{L})$ provokes a decreasing in the yields values, probably due to competition with the monomer for coordination onto the initiator active sites. Thus, it worth to mention that the optimum EDA amount used as a carbene source was of $5 \mu \mathrm{L}$ for the complexes 2ad. Considering that these complexes have the same profile when reacted with EDA, it is possible to affirm that the four complexes have the same pathway in the formation of Ru carbene in the induction period.

The yields increase when increasing the $[\mathrm{NBE}] /[\mathrm{Ru}]$ molar ratio starting from 3000 with yields of 5, 8, 12, and 15\% with $\mathbf{2 a}, \mathbf{2 b}, \mathbf{2 c}$, and 2d, respectively, reaching yields at least twice higher at 5000 for all complexes (Table 5). ROMP is a process governed by thermodynamic equilibrium, where the increase of monomer concentration favors the thermodynamic of polymerization providing higher polymer production [21].

When comparing the catalytic activity of the complexes in ROMP reactions, it is interesting to point out that the reactivity follows this order: $\mathbf{2 a}<\mathbf{2} \mathbf{b}<\mathbf{2} \mathbf{c}<\mathbf{2 d}$. The electronic and steric characteristics of the Schiff base ligands were able to tune the catalytic activity of complexes for ROMP of NBE, highlighting the importance of the Schiff base as ancillary ligand. However, it is reasonable to attribute that the steric effects on the Schiff base play a determinant role for the release of the azomethine group, ratedetermining step for the formation of in-situ active species. Furthermore, this induction period can be faster as using acid $(\mathrm{HCl})$.

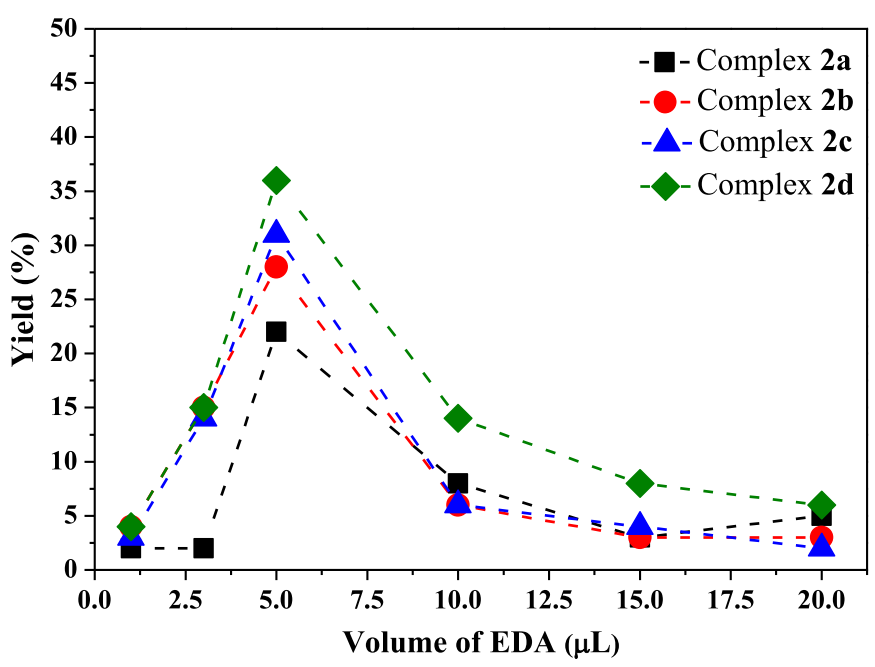

Fig. 5. Dependence of yield on the volume of EDA for ROMP of NBE with 2a-d; [NBE]/ $[\mathrm{HCl}] /[\mathrm{Ru}]=5000 / 25 / 1$ with $1.1 \mu \mathrm{mol}$ of complex in $\mathrm{CH}_{2} \mathrm{Cl}_{2}$ at $25{ }^{\circ} \mathrm{C}$ for $60 \mathrm{~min}$.
Table 4

Yield values and SEC data from the ROMP of NBE with $\mathbf{2 a - d}$ at $25{ }^{\circ} \mathrm{C}$; [NBE]/[HCl]/ $[\mathrm{Ru}]=5000 / 25 / 1$ with $1.1 \mu \mathrm{mol}$ of complex in $\mathrm{CH}_{2} \mathrm{Cl}_{2}$ for $60 \mathrm{~min}$.

\begin{tabular}{lllll}
\hline Complex & Volume of EDA & Yield $(\%)$ & $\mathrm{M}_{\mathrm{n}}\left(10^{3}\right)$ & PDI \\
\hline 2a & 1 & 2 & 5.6 & 1.1 \\
& 3 & 2 & 6.8 & 1.2 \\
& 5 & 22 & 49.2 & 1.2 \\
& 10 & 8 & 7.9 & 1.2 \\
& 15 & 3 & 6.8 & 1.3 \\
\hline $\mathbf{2 b}$ & 20 & 5 & 8.1 & 1.3 \\
\hline & 1 & 4 & 6.8 & 1.2 \\
& 3 & 15 & 71.2 & 1.2 \\
& 5 & 28 & 68.0 & 1.8 \\
& 10 & 6 & 21.8 & 1.2 \\
& 15 & 3 & 7.0 & 1.5 \\
\hline $\mathbf{c c}$ & 20 & 3 & 8.9 & 1.4 \\
& 1 & 3 & 7.2 & 1.3 \\
& 3 & 14 & 62.2 & 1.2 \\
& 5 & 31 & 64.5 & 2.3 \\
& 10 & 6 & 7.4 & 1.4 \\
& 15 & 4 & 7.7 & 1.2 \\
& 20 & 2 & 7.4 & 1.1 \\
\hline 2d & 1 & 4 & 5.9 & 1.1 \\
& 3 & 15 & 60.7 & 1.1 \\
& 5 & 36 & 10.8 & 3.0 \\
& 10 & 14 & 76.5 & 1.1 \\
& 15 & 8 & 19.6 & 1.2 \\
& 20 & & 7.9 & 1.2 \\
\hline
\end{tabular}

Table 5

Yield values and SEC data from the ROMP of NBE with 2 a-d at $25^{\circ} \mathrm{C} ;[\mathrm{HCl}] /[\mathrm{Ru}]=25$ / 1 and $5 \mu \mathrm{L}$ of EDA with $1.1 \mu \mathrm{mol}$ of complex in $\mathrm{CH}_{2} \mathrm{Cl}_{2}$ for $60 \mathrm{~min}$.

\begin{tabular}{|c|c|c|c|c|}
\hline Complex & {$[\mathrm{NBE}] /[\mathrm{Ru}]$} & Yield (\%) & $\mathrm{M}_{\mathrm{n}}\left(10^{3}\right)$ & PDI \\
\hline \multirow[t]{2}{*}{$2 a$} & 3000 & 5 & 70.4 & 1.2 \\
\hline & 5000 & 22 & 49.2 & 1.2 \\
\hline \multirow[t]{2}{*}{ 2b } & 3000 & 8 & 73.4 & 1.3 \\
\hline & 5000 & 28 & 68.0 & 1.8 \\
\hline \multirow[t]{2}{*}{$2 c$} & 3000 & 12 & 72.7 & 1.4 \\
\hline & 5000 & 31 & 64.5 & 2.3 \\
\hline \multirow[t]{2}{*}{ 2d } & 3000 & 15 & 69.8 & 1.2 \\
\hline & 5000 & 36 & 10.8 & 3.0 \\
\hline
\end{tabular}

From the UV-Vis experiments, the kinetic constants of the reaction of the complexes $\mathbf{2 a}-\mathbf{d}$ with $\mathrm{HCl}$ acid $([\mathrm{HCl}] /[\mathrm{Ru}]=25)$ was calculated (Fig. 6). The deprotonation reaction of the azomethine group was pseudo-first order with apparent rate constants $\left(k_{\mathrm{obs}}\right)$ of $2.7 \times 10^{-4}, 4.5 \times 10^{-4}, 6.4 \times 10^{-4}$, and $2.5 \times 10^{-3} \mathrm{~s}^{-1}$ to the complex 2a, 2b, 2c, and 2d, respectively. A decrease in the $k_{\text {obs }}$ values with the increase of the cycloalkyl substituent is observed; it confirms that the reaction between the complexes $\mathbf{2 a - d}$ with the $\mathrm{HCl}$ acid is kinetically favored as the steric hindrance is increased.

Based on this, it is possible to infer that the difference in the reactivity of the studied complexes is directly related to the steric characteristics of the Schiff base ligands, which are modulated by their substituents. Upon metal-carbene formation, a $\mathrm{PPh}_{3}$ leaves the complex, followed by the coordination of NBE to the carbeneRu species. In order to confirm this proposal, experiments in the presence of excess $\mathrm{PPh}_{3}$ (20 equiv.) at $25^{\circ} \mathrm{C}$ for 60 min with [NBE]/ $[\mathrm{HCl}] /[\mathrm{Ru}]=5000 / 25 / 1$ and $5 \mu \mathrm{L}$ of EDA for the complexes 2a-d, which no formation of polymer was observed. This procedure confirms that the ROMP reaction did not occur, although the carbene complex formation took place. The ROMP will only occur when the $\mathrm{PPh}_{3}$ molecule undergoes discoordination from the metal center (Scheme 2). 

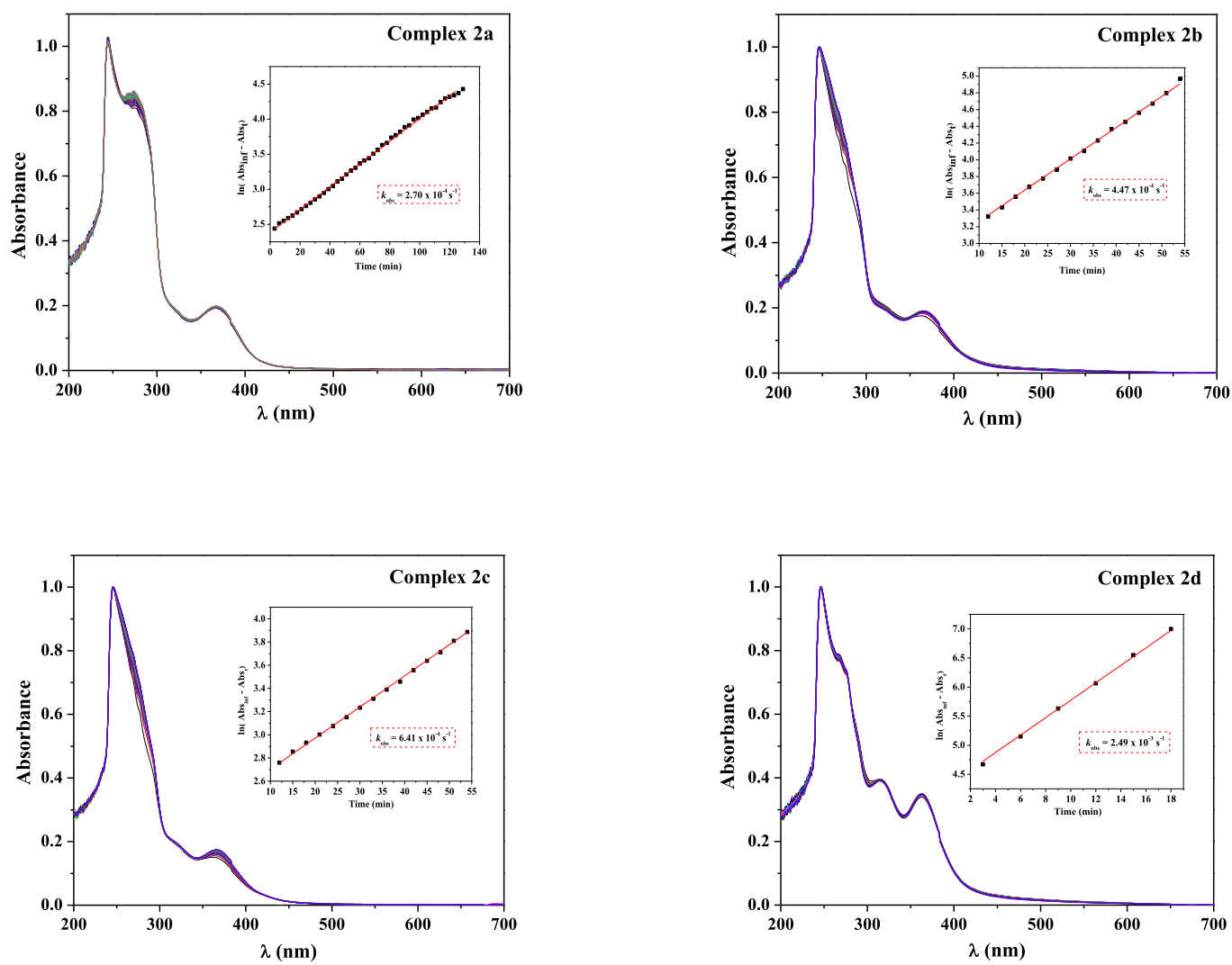

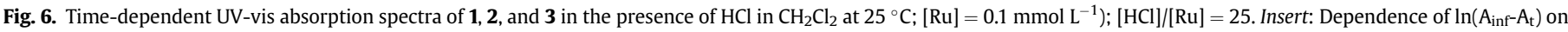
the reaction time at $365 \mathrm{~nm}$.
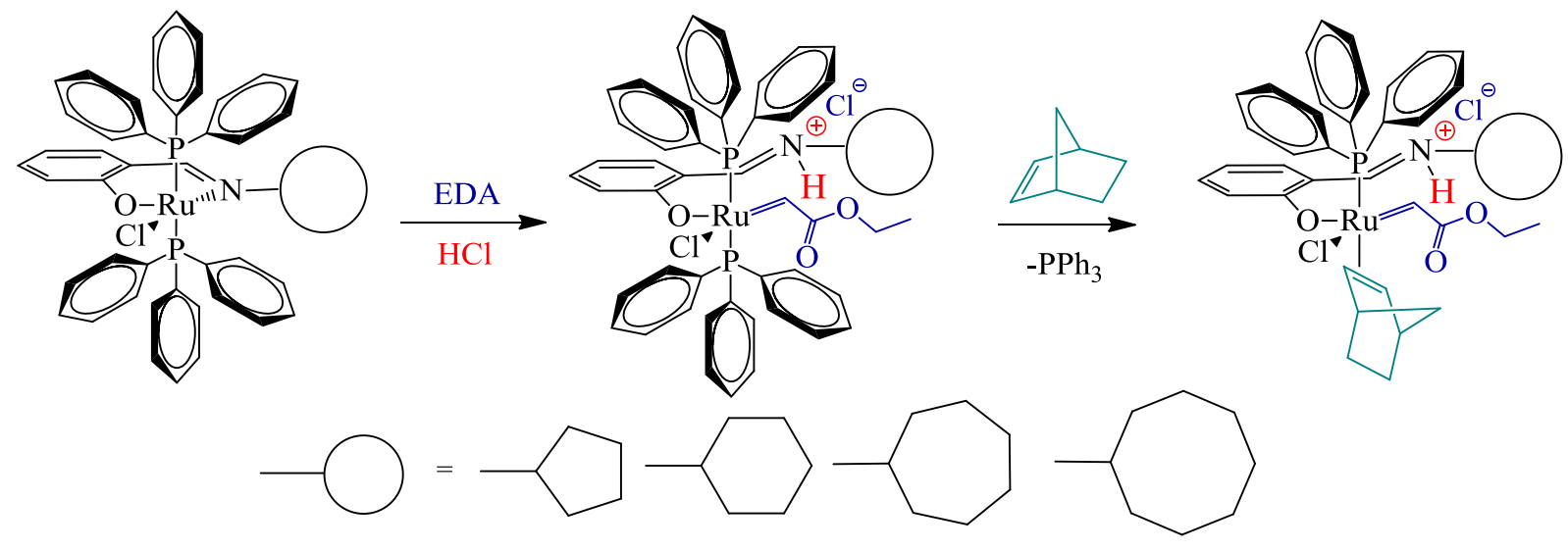

$2 \mathbf{a}$

2b

2c

2d

Scheme 2. Illustration of possible reaction steps for ROMP of NBE with the complexes 2a-d.

\subsection{ATRP reactions}

The complexes 2a-d have properties that make them promising reagents for use as ATRP catalysts. They provide reversible or quasireversible $\mathrm{Ru}^{\mathrm{II}} / \mathrm{Ru}^{\mathrm{III}}$ couples at easily accessible potentials, as shown by the electrochemical data. They have either a vacant coordination site, which makes it possible for a halide ligand to enter the coordination sphere. Thus, MMA polymerization via ATRP with complexes 2a-d were performed as a function of time using EBiB as initiator with $[\mathrm{MMA}] /[\mathrm{EBiB}] /[\mathrm{Ru}]=1000 / 2 / 1 \mathrm{M}$ ratio at $85^{\circ} \mathrm{C}$. The MMA conversion values increase exponentially as a function of time in all cases (Fig. 7). MMA polymerization with 2a achieved a maximum conversion of $47 \%$ of polyMMA and, when catalyzed by $\mathbf{2 b}$, the conversion was increased by $20 \%$, reaching approximately $70 \%$ in $17 \mathrm{~h}$. However, a decrease in conversion values was observed for the complexes $\mathbf{2 c - d}$ under the same conditions.

Kinetics studies of MMA polymerization mediated by the complexes 2a-d show a linear correlation of $\ln \left([\mathrm{MMA}]_{0} /[\mathrm{MMA}]\right)$ as a 

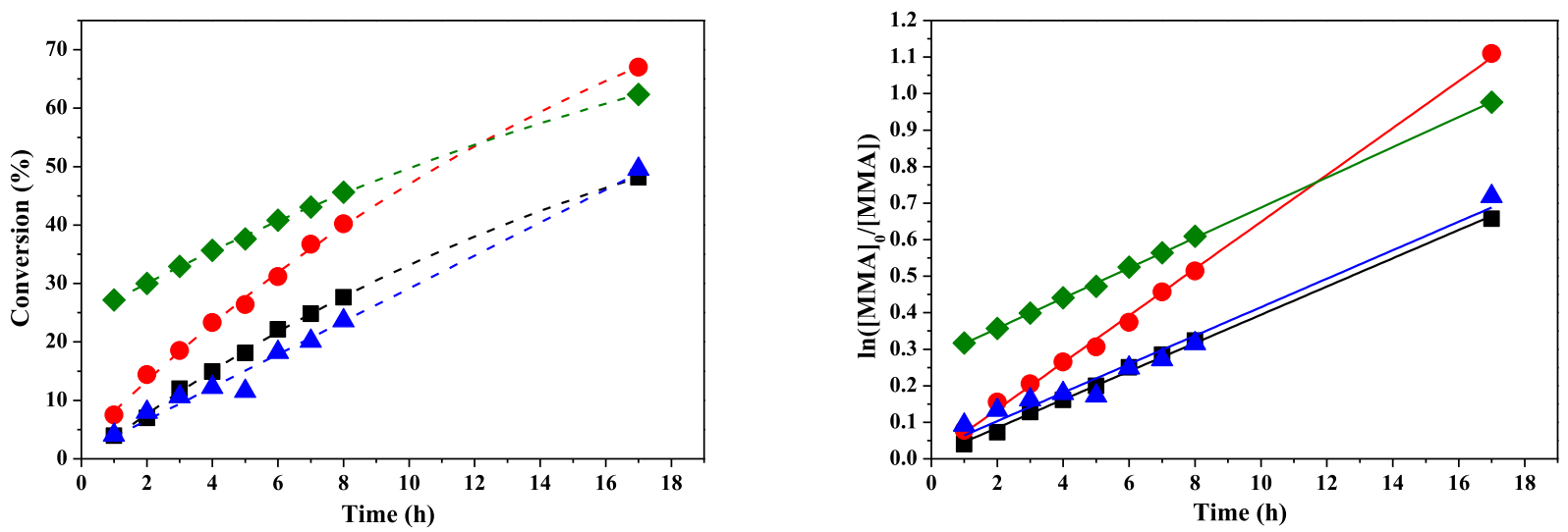

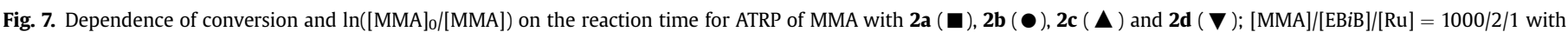
$12.3 \mu \mathrm{mol}$ of complex in $\mathrm{CH}_{2} \mathrm{Cl}_{2}$ at $85{ }^{\circ} \mathrm{C}$.
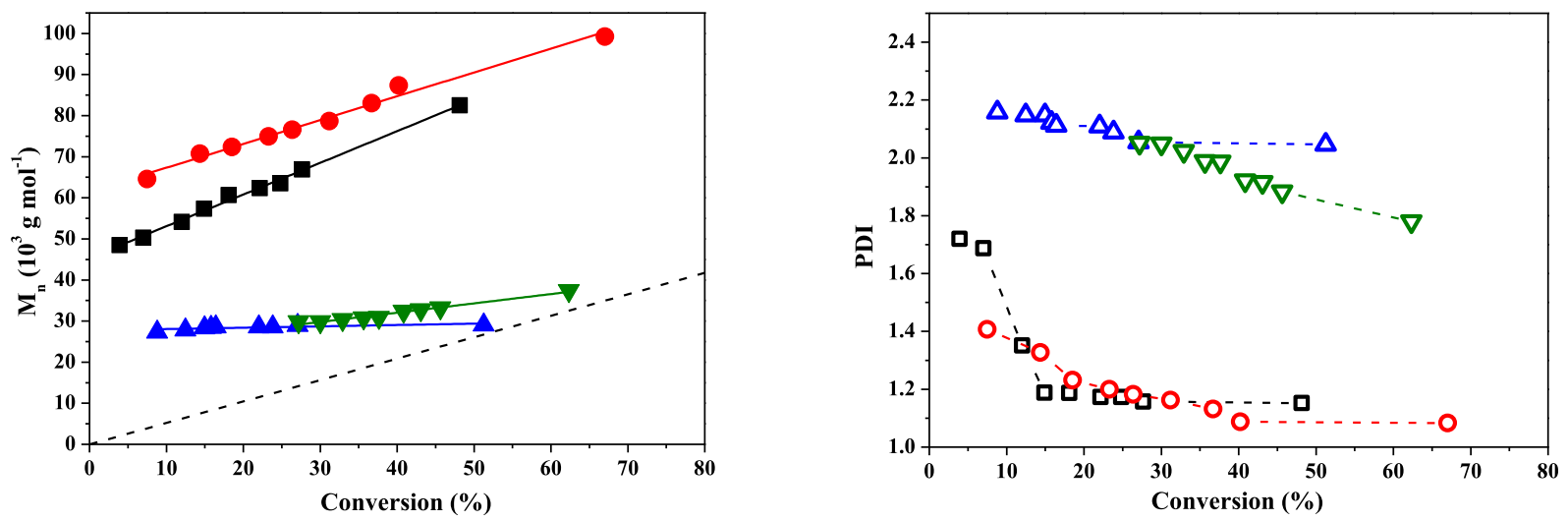

Fig. 8. Dependence of $M_{n}$ and PDI on the conversion for ATRP of MMA with 2a $\mathrm{CH}_{2} \mathrm{Cl}_{2}$ at $85{ }^{\circ} \mathrm{C}$.

function of time (Fig. 7), with a pseudo-first order rate constant $\left(k_{\text {obs }}\right)$ equal to $1.07 \times 10^{-5}, 1.78 \times 10^{-5}, 1.08 \times 10^{-5}$ and $1.15 \times 10^{-5} \mathrm{~s}^{-1}$ for $\mathbf{2 a}, \mathbf{2 b}, \mathbf{2 c}$ and $\mathbf{2 d}$, respectively. The linear semilogarithmic plot of $\ln [\mathrm{MMA}]_{0} /[\mathrm{MMA}] \mathrm{t}$ versus time and the linear increase of molecular weight with conversion, in conjunction with moderate PDIs, illustrates a certain level of control imparted by the complexes 2a-b (Figs. 7 and 8). However, in repeated kinetic experiments molecular weights were observed to be somewhat higher than the theoretical values. This can be attributed to the number of growing radical chains being lower than expected, resulting in an effective increase in the monomer concentration $(f=0.30-0.35)$. On the other hand, the molecular weight of polyMMA obtained with 2c-d showed non-dependence of the molecular weight on the conversion, coupled with PDI of ca. 2.0 clearly illustrating the lack of control during the polymerization. As observed, MMA polymerization suggests that the level of control can be slightly tuned by the substitution pattern of the ancillary ligand in the complexes 2a-d, as more sterically hindered substituents were incorporated into the base Schiff ligand, polymerization control decreased.

\section{Conclusion}

The Schiff bases ligands 1a-d and their respective complexes 2ad were successfully synthesized. The Schiff base-Ru ${ }^{\mathrm{II}}$ complexes $\mathbf{2 a -}$ d were characterized by FTIR, UV-Vis, ${ }^{1} \mathrm{H}-,{ }^{13} \mathrm{C}$ and ${ }^{31} \mathrm{P}$ NMR, and cyclic voltammetry. Complexes $\mathbf{2 a - d}$ were moderately active as catalytic precursors in ROMP of NBE and their catalytic activity was improved in the presence of the $\mathrm{HCl}$ acid using $[\mathrm{NBE}] /[\mathrm{HCl}] /$ $[\mathrm{Ru}]=5000 / 25 / 1$ ratio in the presence of $5 \mu \mathrm{L}$ of EDA for $60 \mathrm{~min}$. The kinetic studies were determinate to explain the reactivity difference between the complexes $\mathbf{2 a - d}$ against the ROMP reactions, it follows this order: $\mathbf{2 a}<\mathbf{2} \mathbf{b}<\mathbf{2 c}<\mathbf{2 d}$. The catalytic activity of the complexes 2a-d suggests that the steric effects on the Schiff base play a determinate role for the release of the azomethine group, rate-determining step for the formation of in-situ active species, and this induction period can be faster as using acid $(\mathrm{HCl})$.

MMA polymerization mediated by complexes $\mathbf{2 a - d}$ was performed using $[\mathrm{MMA}] /[\mathrm{EBiB}] /[\mathrm{Ru}]=1000 / 2 / 1 \mathrm{M}$ ratio at $85^{\circ} \mathrm{C}$. A linear correlation of $\ln \left([\mathrm{MMA}]_{0} /[\mathrm{MMA}]\right)$ as a function of time mediated by complexes 2a-d indicates some level of control in the polymerization as compared to conventional radical polymerization. However, better control levels were achieved with the complexes $\mathbf{2 a - b}$, in which the molecular weights increased linearly with the conversion with narrow polydispersity. On the other hand, complexes 2c-d showed low efficiency in the control of MMA polymerization, evidenced by non-dependence of the molecular weight on the conversion and broad PDIs. It is believed that the steric hindrance of the Schiff base played a decisive role in the reactivity/efficiency against the controlled polymerization of MMA.

\section{Acknowledgements}

The authors are indebted to the financial support from FAPESP 
(Proc. 2013/10002-0).

\section{Appendix A. Supplementary data}

Supplementary data related to this article can be found at https://doi.org/10.1016/j.jorganchem.2017.09.043.

\section{References}

[1] A.M. Abu-Dief, I.M.A. Mohamed, Beni-Suef Univ. J. Basic Appl. Sci. 4 (2015) 119-133.

[2] A. Prakash, D. Adhikari, Int. J. ChemTech Res. 3 (2011) 1891-1896.

[3] P.G. Cozzi, Chem. Soc. Rev. 33 (2004) 410-421.

[4] R.M. Clarke, T. Storr, Dalton Transac 43 (2014) 9380-9391.

[5] K.C. Gupta, A.K. Sutar, Coord. Chem. Rev. 252 (2008) 1420-1450.

[6] R. Drozdzak, B. Allaert, N. Ledoux, I. Dragutan, V. Dragutan, F. Verpoort, Adv. Synth. Catal. 347 (2005) 1721-1743.

[7] R.G. Cavell, K. Aparna, R.P. Kamalesh Babu, Q. Wang, J. Mol. Catal. A. Chem. 189 (2002) 137-143.

[8] S. Matsui, T. Fujita, Catal. Today 66 (2001) 63-73.

[9] Y. Nakayama, H. Bando, Y. Sonobe, T. Fujita, J. Mol. Catal. A. Chem. 213 (2004) $141-150$.

[10] a) Marcus Seitz, G. Helmut, Alt J. Mol. Catal. A Chem. 257 (2006) 73-77;

b) R. Souane, F. Isel, F. Peruch, P.J. Lutz, Comptes Rendus Chim. 5 (2002) $43-48$.

[11] a) Jing Wang, Xinli Zhang, Lu Zhou, Yang Zhou, Qigu Huang, Wantai Yang, J. Appl. Polym. Sci. 132 (2015) 42225;

b) Kefeng Liu, Gang Yao, Wenlei Wu, Bo Gao, Chem. Res. Chin. Univ. 30 (5) (2014) 825-830;

c) M. Mandal, D. Chakraborty, V. Ramkumar, RSC Adv. 5 (36) (2015)
28536-28553;

d) K. Liu, G. Yao, W. Wu, B. Gao, Chem. Res. Chin. Univ. 30 (5) (2014) 825-830.

[12] M.A. Mekewi, Int. J. Polym. Mater. 55 (2006) 219-234.

[13] a) R. Drozdzak, B. Allaert, N. Ledoux, I. Dragutan, V. Dragutan, F. Verpoort Coord. Chem. Rev. 249 (2005) 3055-3074;

b) R. Drozdzak, B. Allaert, N. Ledoux, I. Dragutan, V. Dragutan, F. Verpoort, Adv. Synth. Catal. 347 (2005) 1721-1743;

c) Stijn Monsaert, Nele Ledoux, Renata Drozdzak, Francis Verpoort, J. Polym. Sci. Part A Polym. Chem. 48 (2010) 302-310;

d) Nele Ledoux, Renata Drozdzak, Bart Allaert, Anthony Linden, Pascal Van Der Voort, Francis Verpoort, Dalton Trans. (2007) 5201-5210;

e) Renata Drozdzak, Naoki Nishioka, Gilles Recher, Francis Verpoort, Macromol. Symp. 293 (2010) 1-4.

[14] a) P.W. Armit, A.S.F. Boyd, T.A. Stephenson, J. Chem. Soc. Dalton (1975) 1663; b) P.R. Hoffman, K.G. Caulton, J. Am. Chem. Soc. 97 (1975) 4221;

c) R.C.J. Vriends, G.V. Koten, K. Vrieze, Inorg. Chim. Acta 26 (1978) L29.

[15] M.S. Refat, M.Y. El-Sayed, A. Majid, A. Adam, J. Mol. Struc. 1038 (2013) 62-72.

[16] K.P. Balasubramanian, K. Karvembu, R. Prabhakaran, V. Chinnusamy, K. Natarajan, Spectrochim. Acta, Part A. 68 (2007) 50.

[17] K. Nakamoto, Infrared and Raman Spectra of Inorganic and Coordination Compounds, fourth ed., John Wiley and Sons, Inc., New York, 1986.

[18] M.V. Kaveri, R. Prabhakaran, R. Karvembu, K. Natarajan, Spectrochim. Acta Part A 61 (2005) 2915.

[19] A. Böttcher, T. Takeuchi, K.I. Hardcastle, T.J. Meade, H.B. Gray, D.C. Wikel, M. Kapon, Z. Dori, Inorg. Chem. 36 (1997) 2498.

[20] a) K. Natarajan, R.K. Poddar, C. Agarwala, Oxford, J. Inorg. Nucl. Chem. 39 (3) (1997) 431;

b) A.B.P. Lever, Inorganic Electronic Spectroscopy, second ed., Elsevier, Amsterdam, The Netherlands, 1984;

c) K. Chichak, U. Jacquenard, N.R. Branda, Weinheim, Eur. J. Inorg. Chem. 2002 (2) (2002) 357.

[21] C.W. Bielawski, R.H. Grubbs, Prog. Polym. Sci. 32 (2007) 1-29. 